\title{
Variability in Cenozoic sedimentation and paleo-water depths of the Weddell Sea basin related to pre-glacial and glacial conditions of Antarctica
}

\author{
Xiaoxia Huang *, Karsten Gohl, Wilfried Jokat \\ Alfred Wegener Institute, Helmholtz-Centre for Polar and Marine Research, Am Alten Hafen 26, D-27568 Bremerhaven, Germany
}

\section{A R T I C L E I N F O}

\section{Article history}

Received 22 August 2013

Received in revised form 21 March 2014

Accepted 26 March 2014

Available online 3 April 2014

\section{Keywords:}

seismic reflection

seismostratigraphy

glaciomarine sedimentation

backstripping

paleobathymetry

\begin{abstract}
A B S T R A C T
The Weddell Sea basin is of particular significance for understanding climate processes, including the generation of ocean water masses and their influence on ocean circulation as well as the dynamics of the Antarctic ice sheets. The sedimentary record, preserved below the basin floor, serves as an archive of the pre-glacial to glacial development of these processes, which were accompanied by tectonic processes in its early glacial phase. Three multichannel seismic reflection transects, in total nearly $5000 \mathrm{~km}$ long, are used to interpret horizons and define a seismostratigraphic model for the basin. We expand this initial stratigraphic model to the greater Weddell Sea region through a network of more than 200 additional seismic lines. Information from few boreholes is used to constrain sediment ages in this stratigraphy, supported by magnetic anomalies indicating decreasing oceanic basement ages from southeast to northwest. Using these constraints, we calculate grids to depict the depths, thicknesses and sedimentation rates of pre-glacial (145-34 Ma), transitional (34-15 Ma) and full-glacial (15 Ma to present) units. These grids allow us to compare the sedimentary regimes of the pre-glacially dominated and glacially dominated stages of Weddell Sea history. The pre-glacial deposition with thicknesses of up to $5 \mathrm{~km}$ was controlled by the tectonic evolution and sea-floor spreading history interacting with terrigenous sediment supply. The transitional unit shows a relatively high sedimentation rate and has thicknesses of up to $3 \mathrm{~km}$, which may attribute to an early formation of the East Antarctic Ice Sheet, which was partly advanced to the coast or even inner shelf. The main deposition center of the full-glacial unit lies in front of the Filchner-Ronne Ice Shelf and has sedimentation rates of up to $140-200 \mathrm{~m} / \mathrm{Myr}$, which infers that ice sheets grounded on the middle to the outer shelf and that bottom-water currents strongly impacted the sedimentation. We further calculate paleobathymetric grids at $15 \mathrm{Ma}, 34 \mathrm{Ma}$, and $120 \mathrm{Ma}$ by using a backstripping technique. Our results provide constraints for an improved understanding of the paleo-ice sheet dynamics and paleoclimate conditions of the Weddell Sea region.
\end{abstract}

(c) 2014 Elsevier B.V. All rights reserved.

\section{Introduction}

The breakup of Gondwana and the subsequent opening of the Southern Ocean basins coincided with changes in global ocean circulation and climatic conditions (Jokat et al., 2003) and first-order changes in water mass distribution and marine sedimentation pattern (Brown et al., 2006). Changes in the widths and depths of oceanic gateways and in regional bathymetry influenced ocean current transport and overturning circulation. At present, the Weddell Sea Embayment, at the very southern part of the Atlantic sector of the Southern Ocean, is of particular significance for the generation of deep and bottom-water masses (Orsi et al., 1999; Foldvik et al., 2004). The clockwise rotating Weddell Gyre is responsible for the exchange and mixing of Antarctic Deep Water with

\footnotetext{
* Corresponding author. Tel.: + 4947143811041.

E-mail address: xiaoxia.huang@awi.de (X. Huang).
}

the global circulation system as well as for the transport of Antarctic ice to the Atlantic Ocean through the so-called iceberg alley (Anderson and Andrews, 1999).

Various studies have shown that sedimentary processes in the Weddell Sea basin were strongly influenced by ice sheet dynamics and by ocean circulation (e.g., Jokat et al., 1996; Rogenhagen and Jokat, 2000). At its southern margins, repeated ice advances and retreats sculpted the landscape of the continental shelf and transported sediments to the continental slope and rise (Anderson, 1999). Farther offshore, ocean-current related sedimentation transport processes have produced extensive contourite channel-levee deposits (Weber et al., 1994; Michels et al., 2002). Previous seismostratigraphic studies of the Weddell Sea focused mostly on local scales. Miller et al. (1990) proposed a seismostratigraphic model for the eastern margin of the Weddell Sea. They introduced seven horizons (Fig. 2C). A large hiatus was found at Ocean Drilling Project (ODP) site 693 at the Eocene-Oligocene boundary. 
Kuvaas and Kristoffersen (1991) studied the Crary Fan and its channellevee complex in the southern Weddell Sea. Maldonado et al. (2003, 2005) worked on contourite drifts that result from the interaction of the ACC and Weddell Gyre in the northwestern Weddell Sea. Rogenhagen et al. (2004) improved and expanded Miller et al.'s (1990) study area to the southeastern Weddell Sea by adding new seismic data and calculated sediment thicknesses. Anderson and Wellner (2011) focused on the James Ross Basin and Joinville Plateau in the northwestern Weddell Sea and provided constraints on the ice sheet evolution of the eastern margin of the Antarctic Peninsula based on seismic profiles and shallow boreholes (SHALDRIL). Lindeque et al. (2013) interpreted a long northwest-southeast seismic transect across the southern Scotia Sea and Weddell Sea (Fig. 1, transect B) and proposed a modified seismic horizon stratigraphy based on it.

In this study, we analyze all existing seismic profiles of the Weddell Sea region and attempt to synthesize a unified stratigraphic model by integrating previously published local models with modifications in some cases. We calculate sediment depth, isopach and sedimentation rate grids for the entire basin from pre-glacial to full glacial times. Sediment thicknesses and volumes are estimated from basin-wide seismic horizon correlations using drill sites for stratigraphic control.
We applied a backstripping method in order to analyze the subsidence history and paleobathymetry. The gridded maps are then used to discuss sediment transport and deposition processes corresponding to terrigenous sediment supply, as well as past ice sheet dynamics and ocean circulation of the Weddell Sea basin.

\section{Regional setting and antarctic glacial history}

The Weddell Sea basin experienced more than 180 million years of tectonic, paleoceanographic and paleoclimate history, spanning from its rifting as part of Mesozoic Gondwana break-up to the present (Dalziel and Grunow, 1992; Dalziel, 2007; König and Jokat, 2010). It is bounded to the east by the high-elevation Dronning Maud Land and the East Antarctic Ice Sheet (EAIS), to the west by the mountainous Antarctic Peninsula and its ice sheet (APIS), and to the south by the vast Filchner-Ronne Ice Shelf, which is fed by large ice-streams from both the EAIS and the West Antarctic Ice Sheet (WAIS) (Fig. 1).

Antarctica's glacial history has been investigated using seismic and coring/drill records of marine sediments, glaciomorphological studies, ice cores, and numerical models of paleoclimate and ice sheet dynamics (e.g., Naish et al., 2001; Zachos et al., 2001; DeConto and Pollard, 2003a,



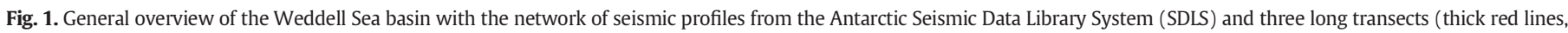

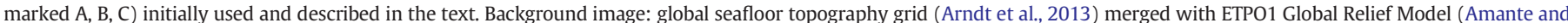

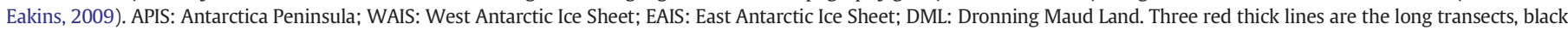

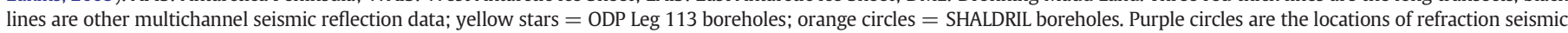
experiments of various expeditions, which were used in setting up the velocity model of the region. 
2003b; Pollard and DeConto, 2005). DeConto and Pollard (2003a, b) proposed that rapid Cenozoic glaciation of Antarctica was induced by declining atmospheric $\mathrm{CO}_{2}$. Results from the Integrated Ocean Drilling Program (IODP) Leg 318 off Wilkes Land have shown that a long-term cooling can be observed between the Early Eocene Climatic Optimum ( 54-52 Ma) and the Middle Miocene ( 15-13 Ma) with the onset of transient cooling episodes in the middle Eocene at $\sim 46-45 \mathrm{Ma}$ (Passchier et al., 2013). There is no evidence that significant ice sheet volumes developed during the middle to late Eocene ( 45-37 Ma). Localized glaciation, predominantly in the form of mountain glaciers and ice caps, occurred in West Antarctica in the early Eocene, although the existence of a larger WAIS in the region cannot be ruled out (Anderson, 1999). A recent paleotopographic reconstruction infers that an early ice sheet covered a larger area of West Antarctica at the Eocene-Oligocene transition than previously thought (Wilson et al., 2012, 2013). Observations from the ANDRILL sediment core recovered from beneath the Ross Ice Shelf document frequent and extended occurrences of open marine conditions in the Ross Sea embayment during the early Pliocene, suggesting that WAIS collapses were common (e.g., Naish et al., 2009). Modeled WAIS variations range from full glacial extents with grounding zones near the continental shelf break, to intermediate states similar to the modern situation, and brief but dramatic retreats, leaving only small isolated ice caps on West Antarctic high lands. Transitions between full-glacial, intermediate and collapsed states are relatively rapid, taking one to several thousand years (Pollard and DeConto, 2009).

\section{Dataset and methods}

\subsection{Seismic dataset}

Our study is based on multichannel seismic datasets that were collected by Germany, the UK, Norway and Spain between 1984 and 2002 and which are archived in the Antarctic Seismic Data Library System (SDLS; Wardell et al., 2007). In total, up to 250 seismic lines are incorporated in this study (Fig. 1). Furthermore, we added five seismic lines (SM01, SM02, SM03, SM04, and SM05) to the database, which were acquired in the northwestern Weddell Sea by a Spanish survey in 1997 (Maldonado et al., 2003). P-wave velocities derived from sonobuoy recordings (Hübscher, 1994; Hübscher et al., 1996) were used to constrain time-to-depth conversions.

Three long transects ( $4900 \mathrm{~km}$ in this study) of seismic reflection data, labeled A, B and C, were used to set up the initial basin-wide seismostratigraphy (Fig. 1). Those profiles were selected to portray the southern continental rise, the central Weddell Sea, and the northeastern Weddell Sea and thus cover nearly the entire basin. We interpreted two Cenozoic unconformities, which can be traced on all three transects, albeit only tentatively in places owing to data gaps and varying data quality. We use Lindeque et al.'s (2013) nomenclature for these two unconformities. WS-u5 and WS-u4 are the boundaries of our three main seismic units, which we label as pre-glacial, transitional, and full glacial.

\subsection{Age information and age model}

Magnetic isochron data were compiled from various studies by Ghidella et al. (2002), König and Jokat (2006), and Maldonado et al. (2007) to provide constraints on basement ages. These isochrons show that the oceanic basement of the Weddell Sea ranges in age from late Jurassic to early Miocene (Livermore and Woollett, 1993; Livermore and Hunter, 1996). The oldest magnetic spreading anomaly runs sub-parallel to the Explora Escarpment and has an interpreted age of 145-137 Ma (Jokat et al., 2003). Further west and north, the western, northern and central Weddell Sea adjacent to the south dates from the period $\sim 118 \mathrm{Ma}$ to $83 \mathrm{Ma}$ (König and Jokat, 2010). The Powell Basin and Jane Basin opened as back-arc basins behind a northwestward directed subduction zone that resulted from the subduction of the
Weddell Sea crust beneath the South Orkney block (Lawver and Gahagan, 1998). Subsequent to the rifting of the Mesozoic continental crust with associated break-up volcanism in the northwestern Weddell Sea, the Powell Basin formed between 29.7 and 21.1 Ma, but the age of the adjacent Jane Basin is controversial, dating either from 17.4 to 14.4 Ma or the period before $30 \mathrm{Ma}$ (Lawver et al., 1991; Eagles and Livermore, 2002; Bohoyo et al., 2007). In summary, the overall ocean spreading of the Weddell Sea ranged from $145 \mathrm{Ma}$ in the southeast to 14.4 Ma in the northwest.

ODP Sites 693 and 692 are located on a mid-slope bench on the Weddell Sea margin. Site 693 with 483.9 m penetration was drilled down to Albian-Early/Lower Cretaceous sediments, separated by a hiatus of $34 \mathrm{Ma}$ from the overlying early Oligocene clayey-mudstones and diatomaceous oozes of our transitional unit (Fig. 2C) (Barker et al., 1988). These sites, thus, provide age control on Cenozoic deposition down to WS-u5 (15 Ma) and WS-u4 (34 Ma). Site 694 (Fig. 2B) in the central Weddell Sea was drilled $391.3 \mathrm{~m}$ to middle Miocene sediments at the lower boundary of the full glacial unit. The oldest sediments encountered at Site 697 (Fig. 2A) in Jane Basin are of early Pliocene age (Barker et al., 1988). SHALDRIL core NBP602A-3C reached a depth of $20 \mathrm{~m}$ below sea floor (Fig. 2D) from the Antarctic Peninsula (Smith and Anderson, 2011), returned Eocene and late Oligocene sediments, and so allowed us to interpret the ages of WS-u4 and WS-u5 in the northwestern Weddell Sea.

\subsection{Time to depth conversion, sediment thicknesses}

In order to convert seismic travel time to depth, we applied a velocity model that is built from all published velocity-depth functions (Kudryavtzev et al., 1987; Hübscher, 1994; Hübscher et al., 1996). The regional velocity-depth functions are similar to that used by Rogenhagen et al. (2004). They incorporated 135 velocity-depth functions (Figs. 1, 3 ), a bathymetry of more than 50,000 data points, and calculated with the general velocity-depth $\left(\mathrm{d}_{\mathrm{s}}, \mathrm{V}_{\mathrm{av}}\right) \mathrm{V}_{\mathrm{av}}=0.17^{*} \mathrm{~d}_{\mathrm{s}}(\mathrm{km})+2.02(\mathrm{~km} / \mathrm{s})$ (Hübscher, 1994, $\mathrm{V}_{\mathrm{av}}=$ average velocity, $\mathrm{d}_{\mathrm{s}}=$ sediment thickness). This step is necessary due to the variability of the bathymetry in the Weddell Sea. We completed the depth conversion procedure using the $\mathrm{TDQ}^{\mathrm{TM}}$ package in LANDMARK. To convert a time data point $\mathrm{x}, \mathrm{y}$, and $\mathrm{t}$ to depth, $\mathrm{TDQ}^{\mathrm{TM}}$ triangulates the $\mathrm{x}, \mathrm{y}$ locations of the nearest timedepth functions, calculating the depth at each corner of the triangle, and then working for $\mathrm{t}$ by linear interpolation between them. However, the distribution of the velocity-depth functions is generally sparse and uneven in the Weddell Sea. Most of the depth-velocity functions are generated in the southeastern Weddell Sea, which means that the estimated depth calculations are likely to be more reliable in the southeast than in the other regions. In the southern Weddell Sea, the profiles are of variable spacing, length and orientation due to the remoteness and harsh ice conditions. Here, we supplemented our data set with published seismic refraction results indicating that the southern Weddell Sea hosts a basin containing up to $10-13 \mathrm{~km}$ thick sediments (Kudryavtzev et al., 1987; Hübscher, 1994; Hübscher et al., 1996, 1998). From these results, we assumed $12 \mathrm{~km}$ as the maximum sediment thickness in front of the Filchner-Ronne Ice Shelf. We subdivided the sediment column into $3-5 \mathrm{~km}$ of pre-glacial, $2 \mathrm{~km}$ of transitional, and 3-5 $\mathrm{km}$ of full-glacial sediments based on proportional relative thicknesses of the seismo-stratigraphic sequences and their correlated ages just to the north.

Gridded isopach maps of the total sedimentary deposit as well as their pre-glacial, transitional and full glacial units were produced by using GMT software. A grid spacing of $0.2 \times 0.1 \mathrm{~min}$ and a low-tension factor of 0.25 were applied in order to interpolate between the widelyspaced data profiles. We set the sediment thickness to zero along the Antarctic coastline where the exposure of igneous and metamorphic basement rocks is known. The volumes of the sedimentary units were calculated by applying the GMT routines grdvolume and grdmask to our thickness grids. 
A) ODP leg 113 site 697

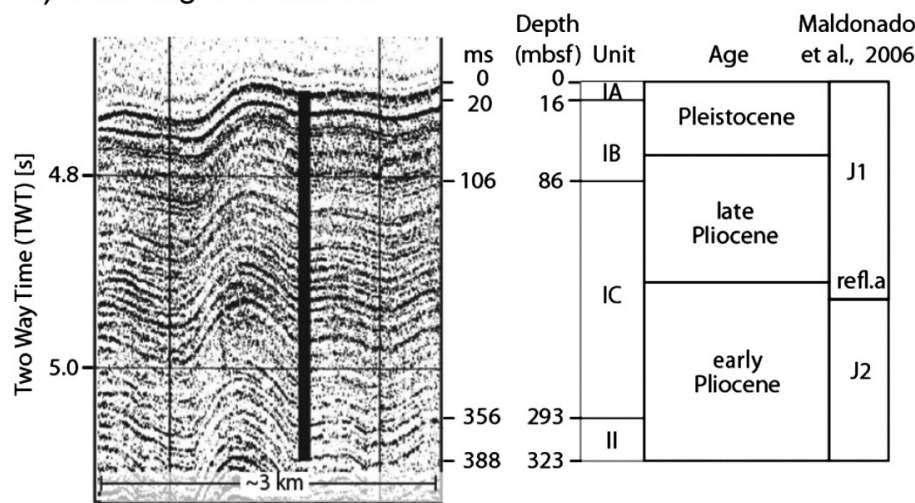

C) ODP leg 113 site 693

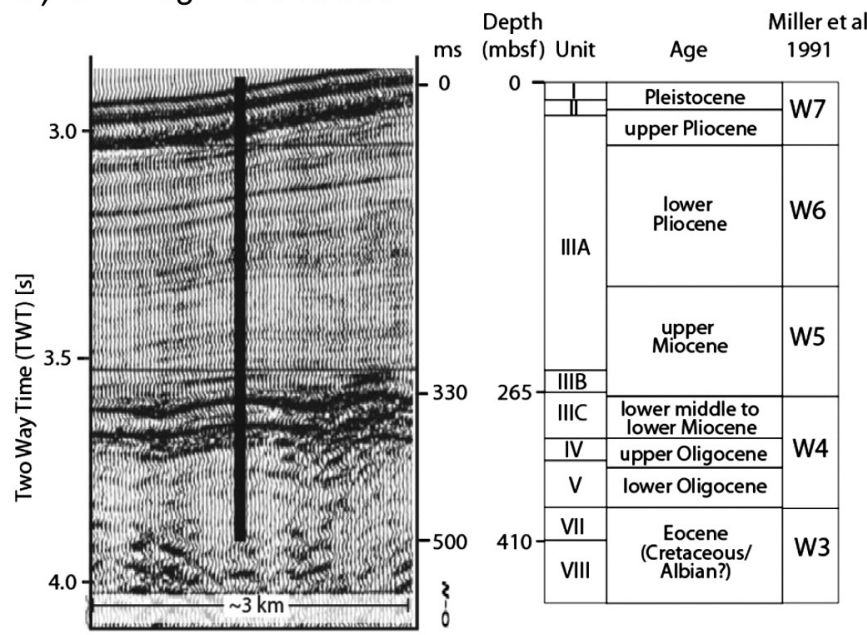

B) ODP leg 113 site 694

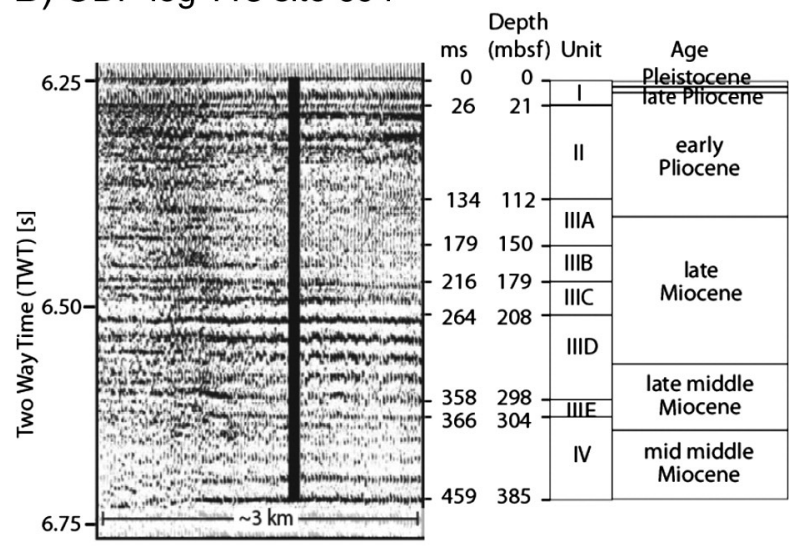

D) SHALDRIL drill core NBP0602A-3C

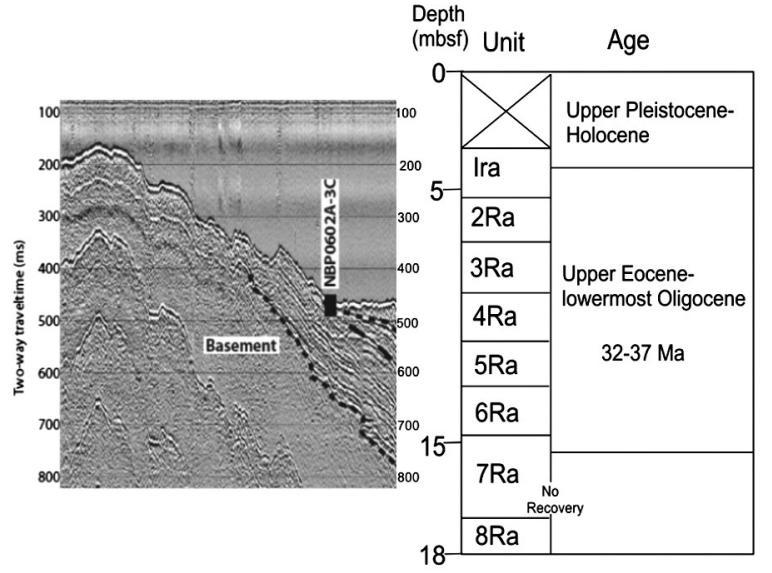

Fig. 2. ODP Sites 693, 697, and 694, and SHALDRIL drill core NBP0602A-3C with age information.

\subsection{Backstripping}

The backstripping technique involves the stepwise removal of sediment loads and applies decompaction of the remaining underlying sequence as well as isostatic correction for the replacement of the sedimentary load by water or air. In this study, for each step five main calculations are applied as below:

1. Removal of the top sedimentary layer:

The respective top sedimentary unit of each downward backstripping step is removed using the calculated thicknesses.

2. Flexural unloading of the lithosphere:

The effects of the sedimentary load on basement subsidence are calculated from the density and thickness of the sedimentary units at the time they were deposited. We calculate the flexural response of a lithosphere approximated as an elastic beam to loading using functions by Watts (2001).

3. Decompaction of the remaining sediments:

We used a single porosity-depth relationship from ODP Leg 113 (Barker et al., 1988; Fig. 3). This relationship is best stated as an exponential function $\phi(y)=\phi_{0} \exp \left(-c^{*} d\right)$, in which $\phi_{0}$ is the porosity at the top of the sediment column, $\mathrm{d}$ is the depth in the column, and $\mathrm{c}$ is a constant.

4. Thermal subsidence:

The bathymetric effects of thermal contraction, densification, and isostatic equilibration of cooling lithosphere are added to the corrections from the backstripped model from estimates of oceanic crustal age, crustal stretching factor and rift age. The cooling of oceanic lithosphere causes its bathymetric surface to deepen in proportion to the square root of its age (Parsons and Sclater, 1977). In the southernmost areas, the stretched continental lithosphere will have subsided in a similar way as its geotherm returned to a pre-stretching state. This subsidence can be approximated with an exponential age-relation (McKenzie, 1978). The age information for the Weddell Sea basin (Fig. 4) is based on a new compilation of magnetic isochrons and age grids (Livermore and Woollett, 1993; Livermore and Hunter, 1996; Müller et al., 2008). Fixed parameters applied in the calculations are listed in Table 2. We use an average stretching factor of 2.5 for the extended continental lithosphere as estimated by Hübscher et al. (1996), Jokat et al. (1996) and König and Jokat (2006).

5. Sea-level correction:

Sea-level changes have the same isostatic effects as loading or unloading by sediments. We corrected for this effect from the difference in the sea-level height between the present and the time when the sediment unit was deposited, using the global sea-level curve of Miller (2005).

\section{Results}

\subsection{Seismic characteristics and stratigraphy}

The acoustic basement itself is very rugged in the northwestern Weddell Sea with several seamounts breaking through to the seafloor 


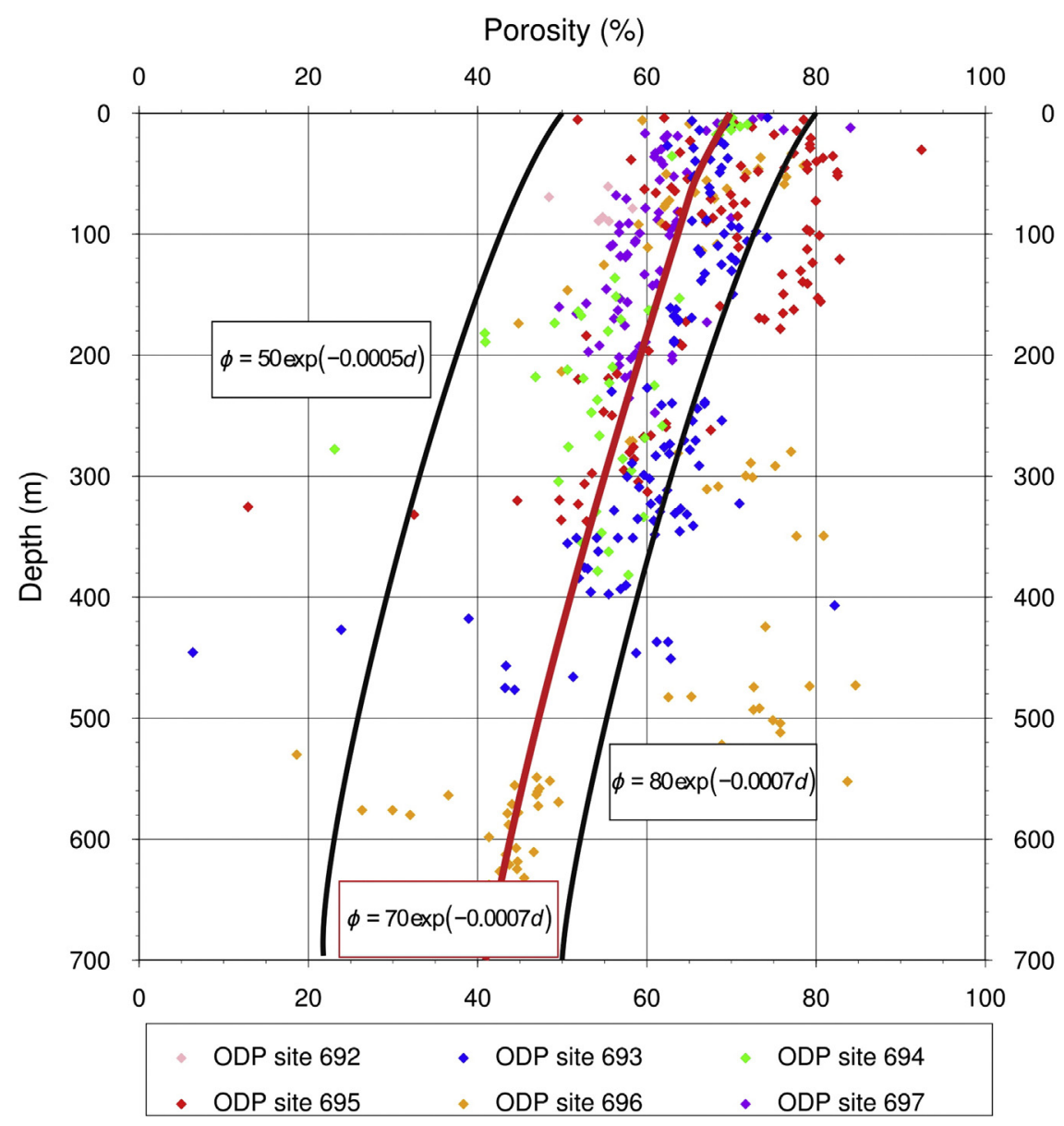

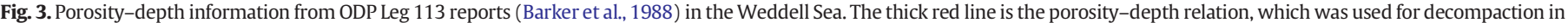
this study $\phi_{0}=70, c=0.0007$. Another two porosity-depth relations showed by two black thick lines, which were used for error estimation.

(Figs. 6, 7), whereas the basement in the central Weddell Sea is less rugged (Fig. 6 , between 600 and $1100 \mathrm{~km}$ ). The acoustic basement of transect A, along the southern and southwestern continental rise, is rather gentle (Fig. 5). Most of the seismic profiles in the Weddell Sea show three clearly distinguishable sedimentary units (Table 1 ) above the acoustic basement.

The first unit is characterized by these features: sub parallel wavy reflectors, lower amplitude sequences with partly strong discontinuous reflections and horizontal, spaced transparent zones (Figs. 5, 6, 7). Early Cretaceous organic-rich mudstones from this unit were drilled at ODP Site 693 off the southeastern Weddell Sea margin (Barker et al., 1988). Following Lindeque et al. (2013), we interpret it as a preglacial unit. We follow Lindeque et al's (2013) stratigraphic model for this unit in the central Weddell Sea along transect B (Fig. 6) and expand it to the wider region by correlating the seismic characteristics with those of transects A and C. Our unconformity WS-u4 marks the upper boundary of the pre-glacial unit and is consistent with unconformity W4 of Miller et al. (1990). They interpreted the unconformity as the product of a major erosional event.

The second unit is characterized by medium acoustic response and laminated reflections. Chaotic facies are separated by thin draping layers of medium reflectivity and by partly semi-transparent zones (Figs. 5, 6). Early Oligocene silty and clayey mud and sandy mudstones from this unit were drilled at ODP Sites 693 and 696 (Barker et al., 1988). We interpret it as the transition unit, which is separated from the upper unit by an unconformity mapped as WS-u5, which represents a prominent and widespread unconformity corresponding to reflector W5 of Miller et al. (1990). This reflector is also coincident with 'Reflector c', the most prominent unconformity in the northwestern Weddell Sea (Maldonado et al., 2005). In the southern Weddell Sea, WS-u5 coincides with the horizon W4 of Rogenhagen et al. (2004) and is interpreted to represent the onset of glacially-dominated sedimentation processes.

The third unit is generally characterized by a regular and thinly bedded pattern of parallel, continuous high-amplitude reflections. Locally, this pattern is interrupted by chaotic reflections with lower reflectivity in the southern Weddell Sea (Fig. 5). We interpret this unit as full glacial, which is bounded by the seafloor and WS-u5. Abundant drifts and channel-levee systems are present on the southern continental rise (Michels et al., 2002). The sediment drifts show semi-transparent, continuous, sub-parallel or irregular, wavy to discontinuous as well as moderate to low amplitude reflectors (Fig. 5). The acoustic facies of the channel-levee systems vary greatly between the drifts. Some channel floors are characterized by high-amplitude, discontinuous reflectors, and surrounded by transparent facies. Levees are shown by relatively well-stratified deposits that abruptly wedge out at the side of channels (Fig. 5). Glacial turbidites are recorded at ODP Site 694 as well as in the significant Ice Rafted Debris (IRD) of Miocene sequences at ODP Site 693 (Barker et al., 1988).

\subsection{Sediment thicknesses and rates}

The total sedimentary thickness was interpolated between seismic lines and clipped where no sufficient data coverage exists (Fig. 8A). Generally, the grid shows a trend of decreasing total sediment thicknesses from the continental margin to the abyssal plain of the Weddell Sea. Most sediment was deposited on the continental shelf and slope, 


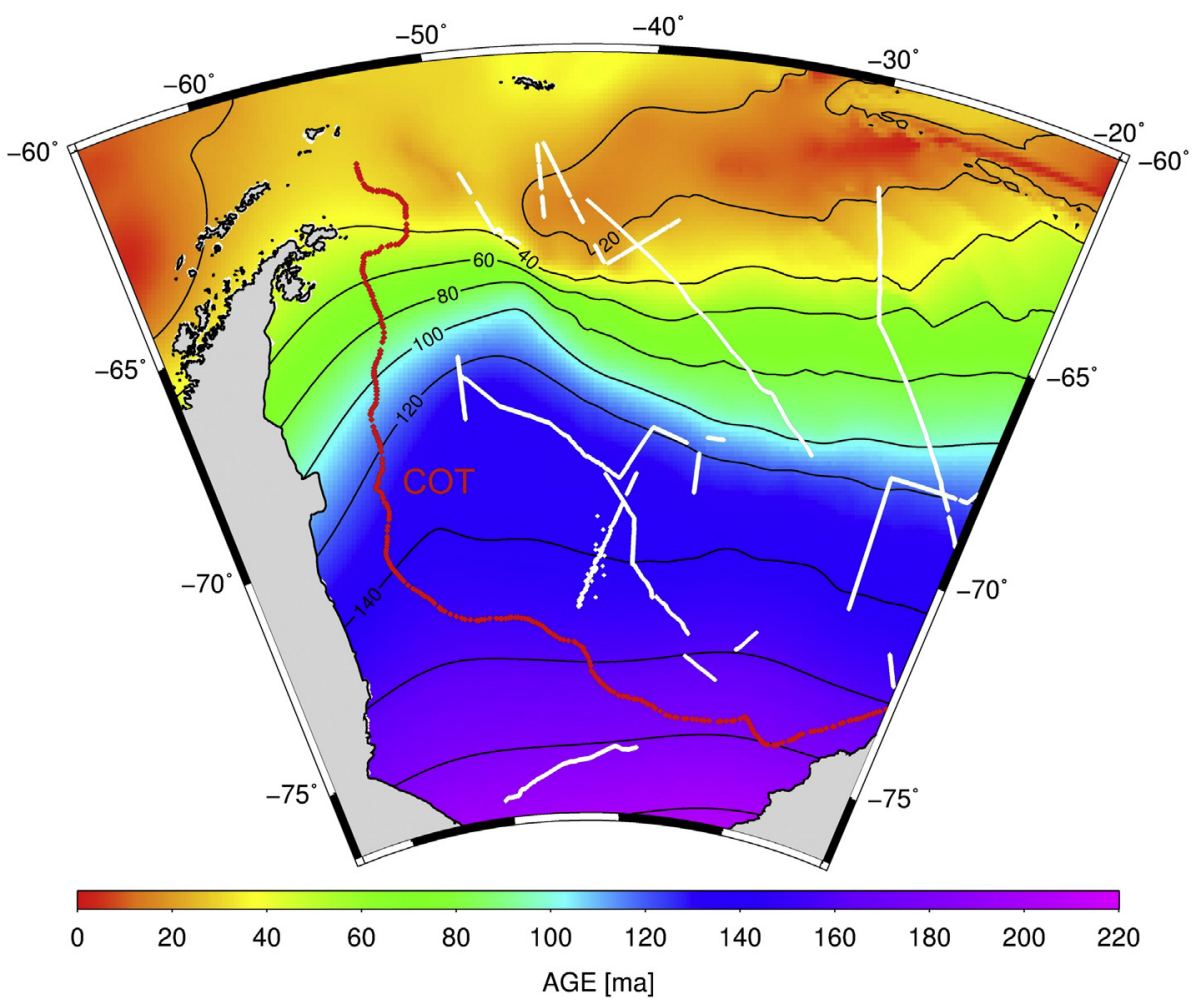

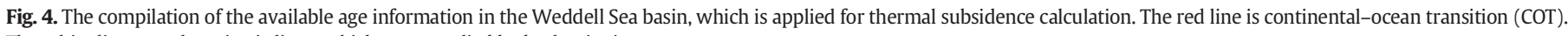
The white lines are the seismic lines, which were applied by backstripping.

with large depocenters in front of the Filchner-Ronne Ice Shelf and along the southern continental rise of the Weddell Sea. Here, interpretations of seismic refraction data suggested up to $12 \mathrm{~km}$ of sedimentary infill. The Crary Fan occupies a large depression filled with more than $8 \mathrm{~km}$ thick sediments in the southeastern Weddell Sea (Fig. 8A). Haugland et al. (1985) identified the fan from multichannel seismic data and interpreted it as an accumulation of glacially-transported material. Kuvaas and Kristoffersen (1991) also described the structure of the fan in detail. Another major sediment depocenter with $5 \mathrm{~km}$ of sediment exists off the continental slope of the eastern Antarctica Peninsula. The sedimentary deposits of the northern Weddell Sea reach a maximum thickness of only $2 \mathrm{~km}$, partly reflecting the much

Table 1

Summary of the seismic stratigraphy of the deposition sequences and major paleoceanography events.

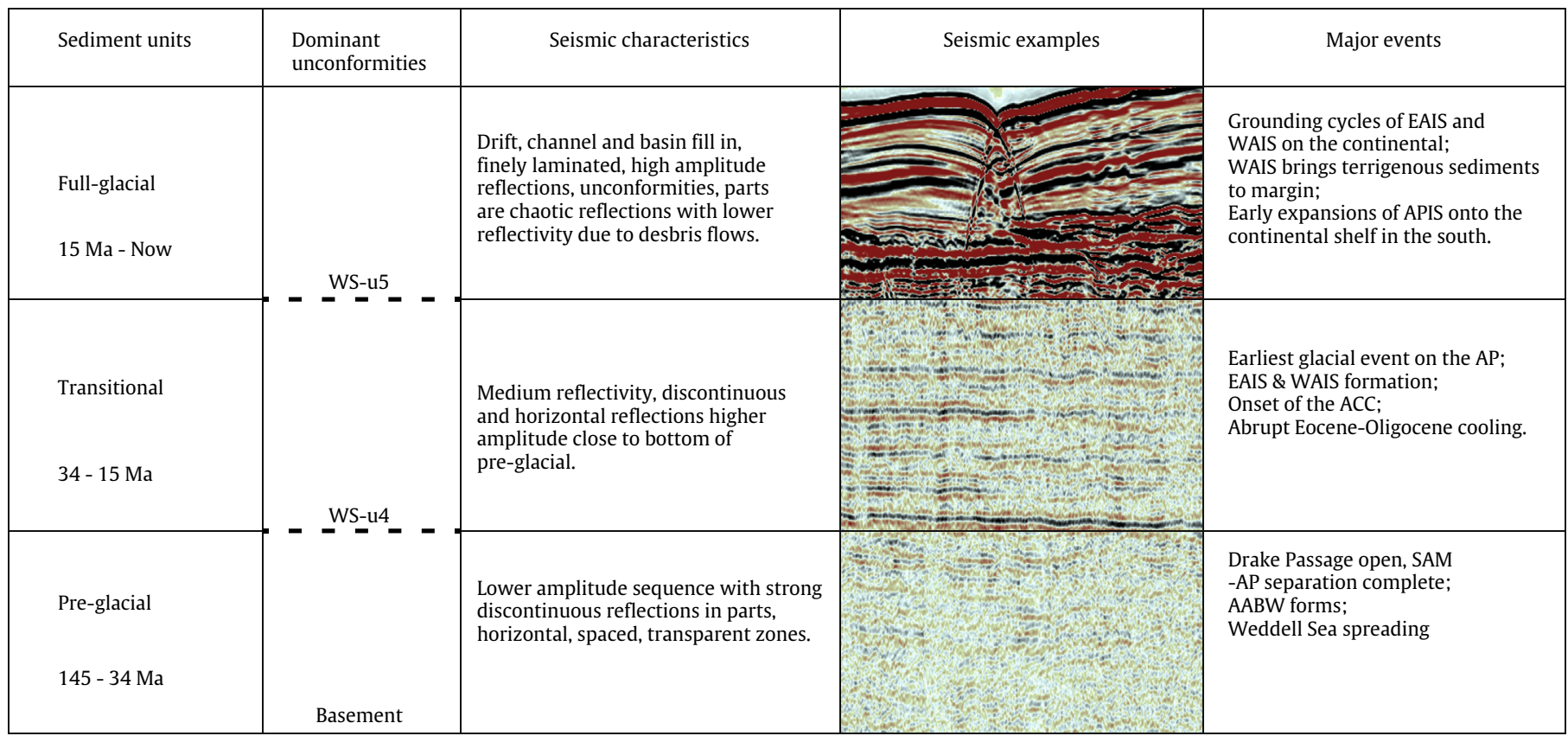


Table 2

Parameters used for the subsidence calculation of rifted crust.

\begin{tabular}{lll}
\hline Parameter & Name & Value \\
\hline $\mathrm{a}$ & Lithosphere thickness & $125 \mathrm{~km}$ \\
$\rho_{\mathrm{w}}$ & Density of sea water & $1.03 \mathrm{~g} / \mathrm{cm}^{3}$ \\
$\rho_{\mathrm{m}}$ & Density of mantle & $3.3 \mathrm{~g} / \mathrm{cm}^{3}$ \\
$\alpha$ & Thermal expansion coefficient & $3.1 * 10^{-5} 1 /{ }^{\circ} \mathrm{C}$ \\
$\mathrm{T} 1$ & Asthenosphere temperature & $1365^{\circ} \mathrm{T}$ \\
$\tau$ & Thermal time constant & $62.8 \mathrm{Ma}$ \\
\hline
\end{tabular}

younger crust in this region. Only thin $(<3 \mathrm{~km})$ sedimentary sequences were deposited on the Explora Escarpment off the Dronning Maud Land margin.

Following the observed trend from the total sedimentary thickness grid, the thickness of the pre-glacial unit also decreases from the continental margin towards the deep sea (Fig. 8B). Its greatest thickness, of $5 \mathrm{~km}$, is found in front of the Filchner-Ronne Ice Shelf. The continental margin of the western Weddell Sea seems to host a series of small depocenters with a maximum thickness of $4 \mathrm{~km}$. In the northern and eastern Weddell Sea, the pre-glacial sediment thickness is only about $0.5 \mathrm{~km}$.

According to our stratigraphic model, the transitional unit started being deposited at about $34 \mathrm{Ma}$, and its deposition lasted about 5 million years in the northeast and 20 million years in the southwest. As is the case for the pre-glacial unit, the main depocenters lie in the southern Weddell Sea, where the maximum sediment thickness of this unit reaches $2.5 \mathrm{~km}$ (Fig. 8C).

The thicknesses of the full-glacial unit range from 0 to $5 \mathrm{~km}$. The main depocenter overlies those of the pre-glacial and transitional units (Fig. 8D). With respect to the number of the seismic lines, small separate depocenters are observed within this unit, e.g. in the northwestern Weddell Sea. Some medium-sized depocenters with maximum thicknesses of about $3 \mathrm{~km}$ are found at the eastern Antarctica Peninsula margin and along the margin off the Dronning Maud Land, which correspond to the small sedimentary basins on the seismic profile we observed.

The total sedimentary volume for the Weddell Sea can be calculated to be $3.89 \times 10^{6} \mathrm{~km}^{3}$ with contributions by the pre-glacial unit of $1.60 \times 10^{6} \mathrm{~km}^{3}$, the transitional unit of $0.51 \times 10^{6} \mathrm{~km}^{3}$ and the fullglacial unit of $2.0 \times 10^{6} \mathrm{~km}^{3}$.

Sedimentation rates were derived on the basis of the age ranges and gridded sediment thicknesses of the pre-glacial, transitional, and fullglacial units. We used sites along the three long transects $A, B$, and C and sites from seismic profiles in various other locations in order to obtain a roughly regular point grid to calculate the sedimentation rates. We gridded the calculated sedimentation rates for each unit in order to show temporal and spatial trends in sediment deposition processes in the Weddell Sea (Fig. 9). The pre-glacial unit deposited at relatively slow sedimentation rates, in particular in the southeastern and northeastern Weddell Sea, where the rates vary from 10 to $25 \mathrm{~m} / \mathrm{Myr}$, compared to about $40 \mathrm{~m} / \mathrm{Myr}$ in front of the Filchner-Ronne Ice Shelf. In some of the small basins of the northwestern Weddell Sea, the value increases up to $80 \mathrm{~m} / \mathrm{Myr}$. In contrast to the pre-glacial unit, higher sedimentation rates are found for the transitional unit, particularly in the southern Weddell Sea, where the rate is $100-160 \mathrm{~m} / \mathrm{Myr}$. In the central Weddell Sea, the rate varies from 40 to $80 \mathrm{~m} / \mathrm{Myr}$. During full-glacial times, sediments were deposited with rates from 120 to $200 \mathrm{~m} / \mathrm{Myr}$.

\subsection{Backstripping and paleobathymetry}

The backstripping calculations in steps 1-3 are completed along seismic profiles for horizons aged $15 \mathrm{Ma}$ (lower boundary of full glacial), $34 \mathrm{Ma}$ (lower boundary of transitional), and $120 \mathrm{Ma}$ (none deposition), which are based on the interpretation of Miller et al. (1990), Rogenhagen et al. (2004) and Lindeque et al. (2013) (Fig. 10). The horizon at $120 \mathrm{Ma}$ was selected to represent an early opening stage of the Weddell Sea basin in the Cretaceous, 34 Ma represents the dominant Eocene-Oligocene transition from the Cenozoic greenhouse to the icehouse world with suggested onset of the ACC, and $15 \mathrm{Ma}$ represents the middle Miocene for which paleoclimate records indicate a major intensification of Antarctic glaciation (Anderson and Andrews, 1999). The resulting backstrip corrections are gridded to produce a gradually-varying field from deeper to shallower across the Weddell Sea. The thermal and paleobathymetric corrections are calculated directly from the age grid. A set of paleobathymetric models is generated by adding all of the corrections to the present-day bathymetry. The models (Fig. 10) yield a consistent trend of deepening in the regional evolution of the Weddell Sea basin. This is consistent with the overall dominance of thermal subsidence effects. At $120 \mathrm{Ma}$, the basement, which currently lies beneath as much as $12 \mathrm{~km}$ of sediments, is restored to a level of only $\sim 3 \mathrm{~km}$ below seafloor. At the Eocene-Oligocene boundary (34 Ma), the grids show that the basin is about $0.5-1 \mathrm{~km}$ shallower compared with that of the present in the northwestern Weddell Sea, which is mainly due to the fact that relative young oceanic crust yields remarkable effect of the thermal subsidence. However, the paleowater depth of the central Weddell Sea is nearly consistent with today and the Middle Miocene. The small elevation difference is probably caused by the mantle rebound and decompaction of the remaining sediments after removal of 5-6 km sediment layers, which were mostly deposited during glacial time (Fig. 8). The effect of the thermal subsidence is nearly negligible in the central Weddell Sea for the period from $15 \mathrm{Ma}$ to present day.

\section{Discussion}

The development of the Weddell Sea basin witnessed the interplay of complex seafloor spreading and tectonic processes with the deposition of large amounts of sediments since the Jurassic. For instance, as reported from seismic refraction experiments in the southernmost Weddell Sea in front of the Filchner-Ronne Ice Shelf, 10-12 km of sediments overlies a basement of stretched continental crust (Hübscher et al., 1996; Kudryavtzev et al., 1987; Leitchenkov et al., 2008). Here, pre-glacial sedimentation processes were likely dominated by thermal lithospheric subsidence and variations in terrigenous sediment supply. Later, the developing and fluctuating Antarctic ice sheets have supplied sediments which interacted with intensified ocean circulation in the Weddell Sea to play a significant role in transporting and distributing sediments, particularly after the opening of Drake Passage/Scotia Sea gateway and intensification of the ACC.

\subsection{Pre-glacial regime}

The pre-glacial unit contains sediments deposited within a large time range of up to 116 million years, spanning from Mesozoic deposits on the oldest oceanic basement in the southwestern Weddell Sea (about $145 \mathrm{Ma}$ ) to the Eocene-Oligocene transition (about $34 \mathrm{Ma}$ ). The long history of thermal lithospheric subsidence in the southern and southeastern Weddell Sea and the proximity to terrigenous sediment supply have resulted in the large deposit thicknesses along the continental margin of the Dronning Maud Land and the FilchnerRonne shelf (Fig. 9B, Fig. 11). Plate-kinematic reconstructions (König and Jokat, 2006) demonstrate that the Weddell Sea rift evolved into a large basin already in the Early Cretaceous, creating the wide embayment of the Filchner-Ronne Basin between the elevated regions of the southern Antarctic Peninsula, the Ellsworth-Whitmore Mountains of West Antarctica and Dronning Maud Land of East Antarctica. King (2000) proposed that the Weddell Sea embayment is likely to have been a major depocenter since the Jurassic. The reconstructed Antarctic paleotopography of Wilson et al. (2012) suggests the continued presence of a low-lying basin in this region in the late Eocene. As most of the period of sediment deposition during pre-glacial times falls into 


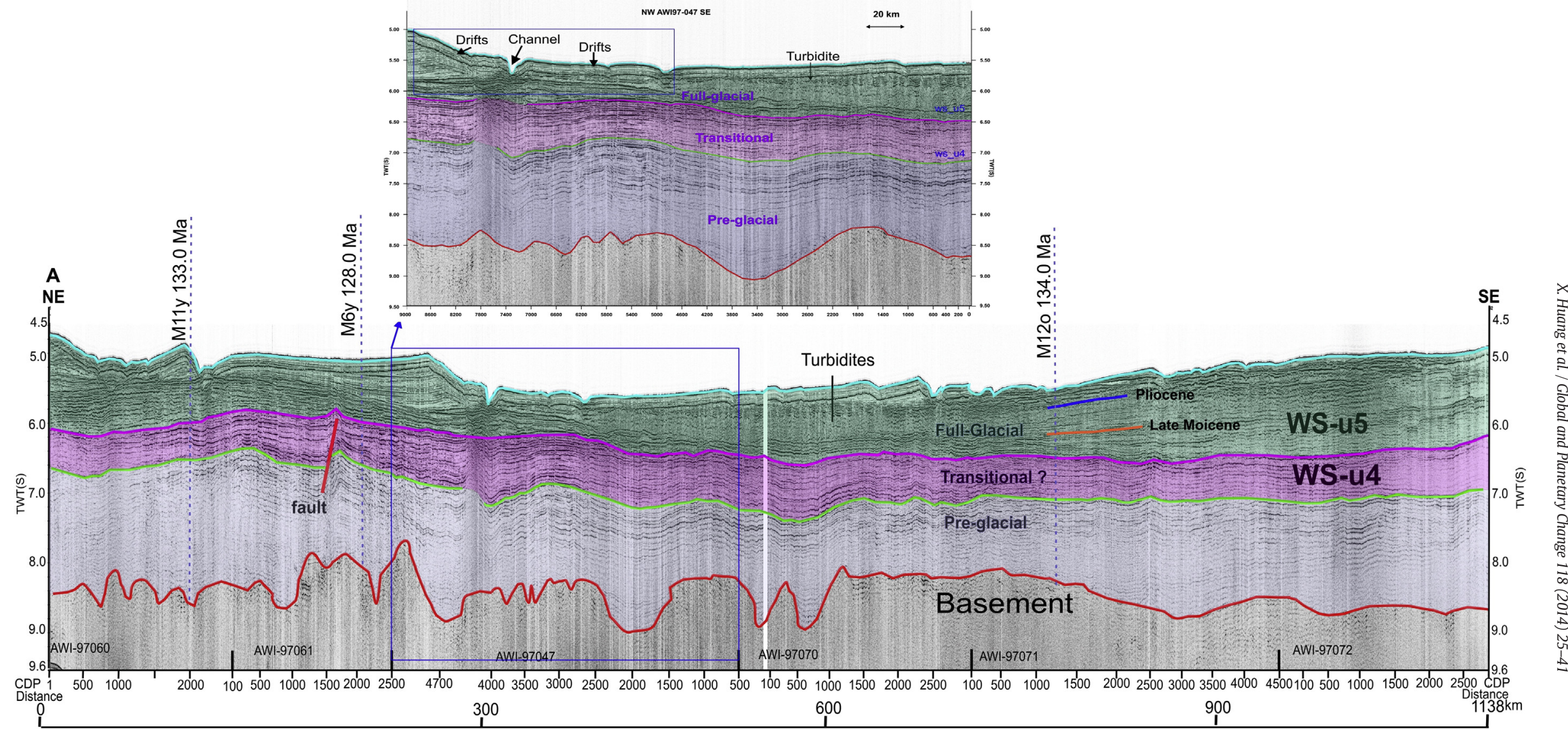

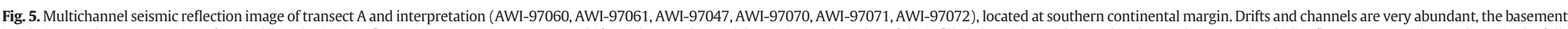

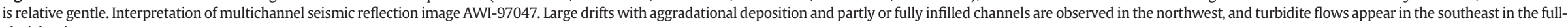
glacial unit. 


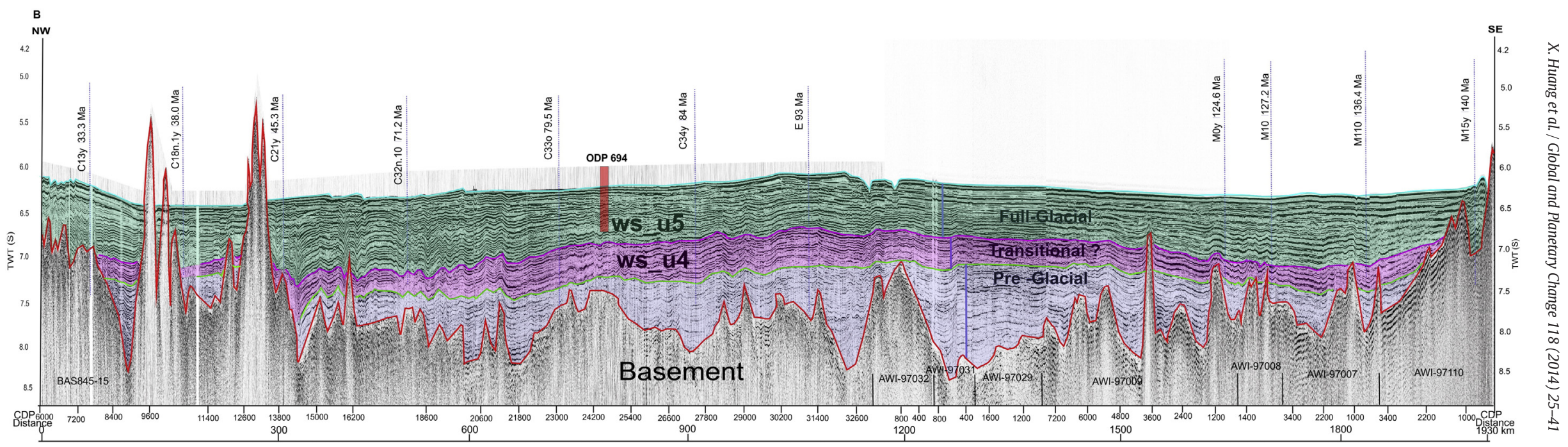

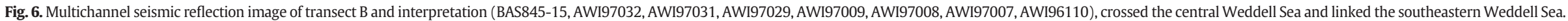




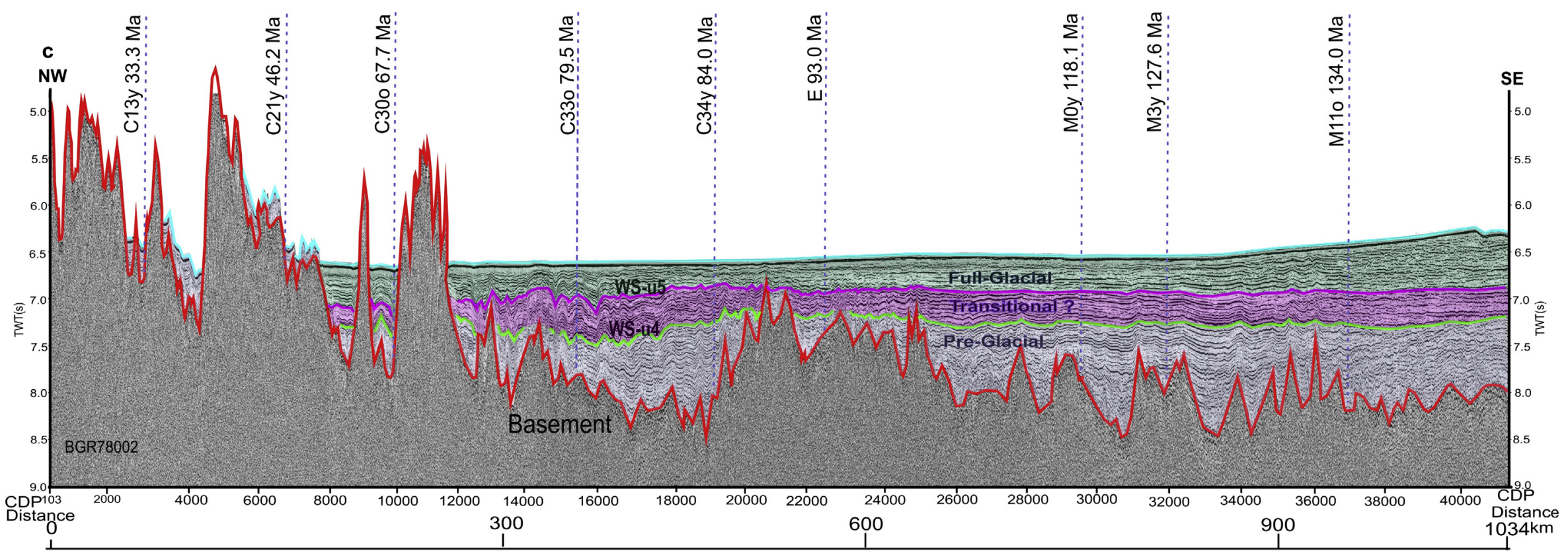

Fig. 7. Multichannel seismic reflection data of transect C (BGR78002) crossing the eastern and northeastern region of the Weddell Sea. Very rugged basement and seamounts were found in the north. 
A
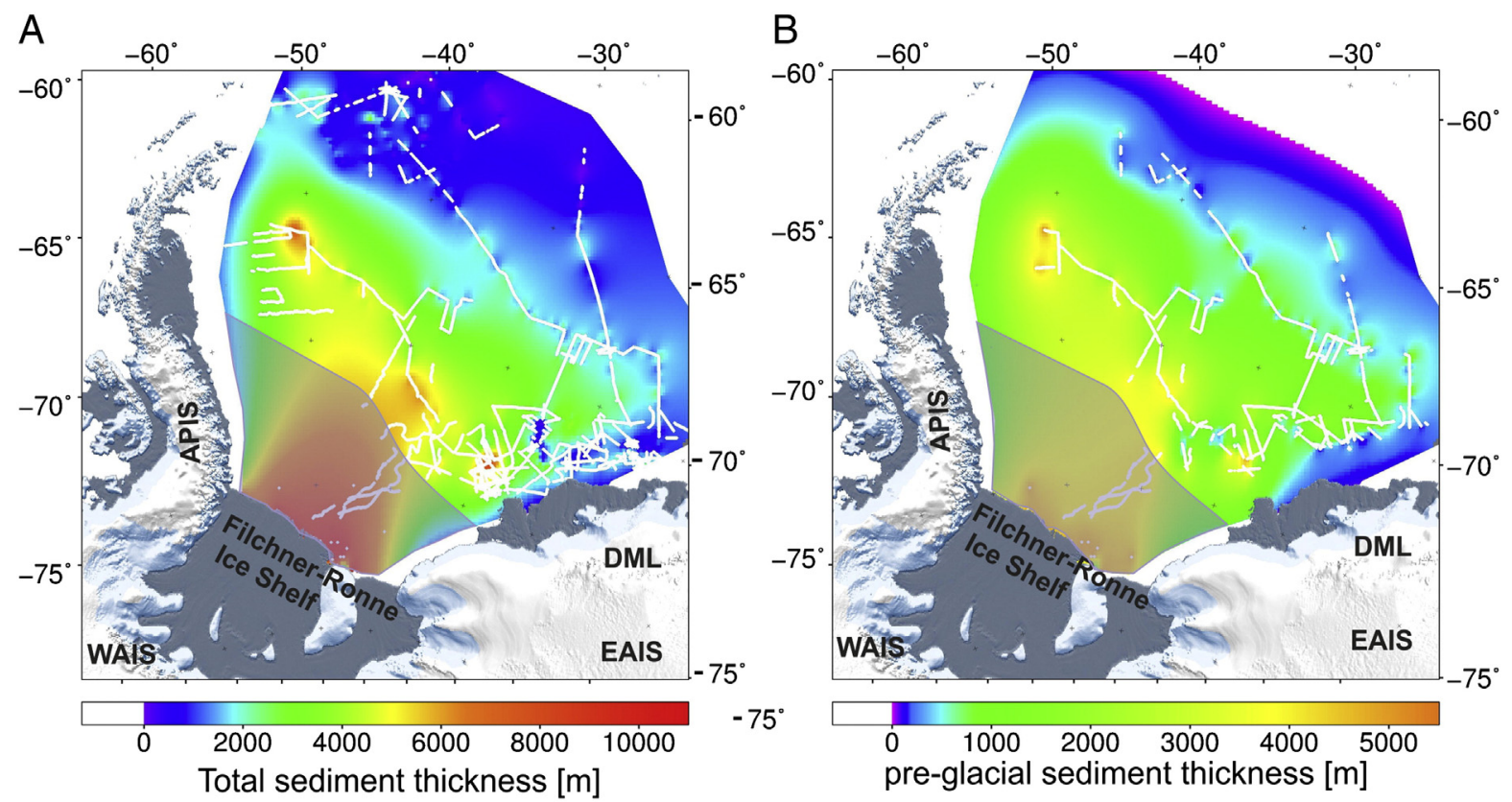

C

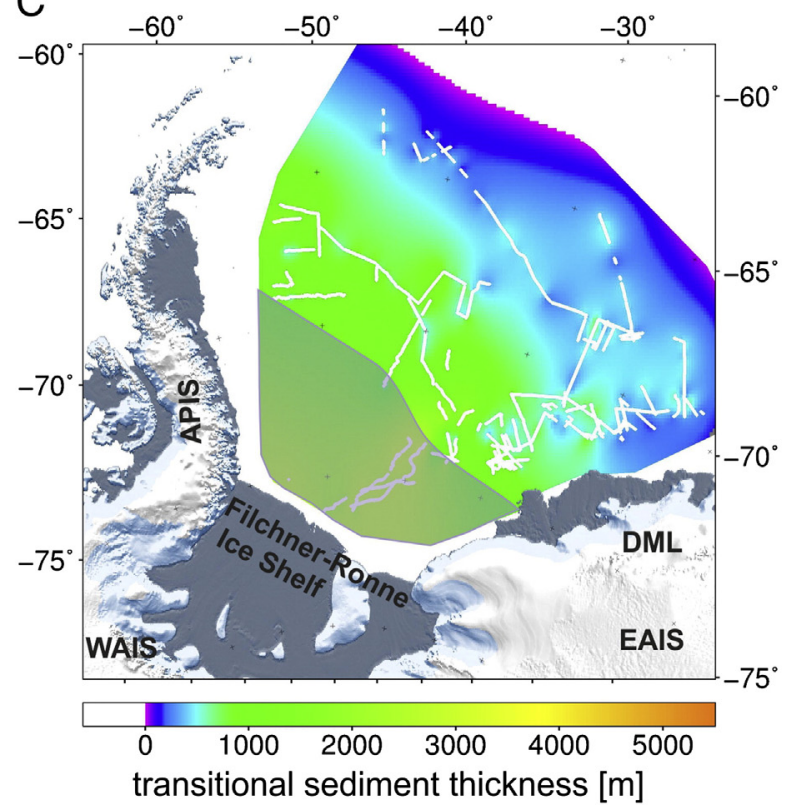

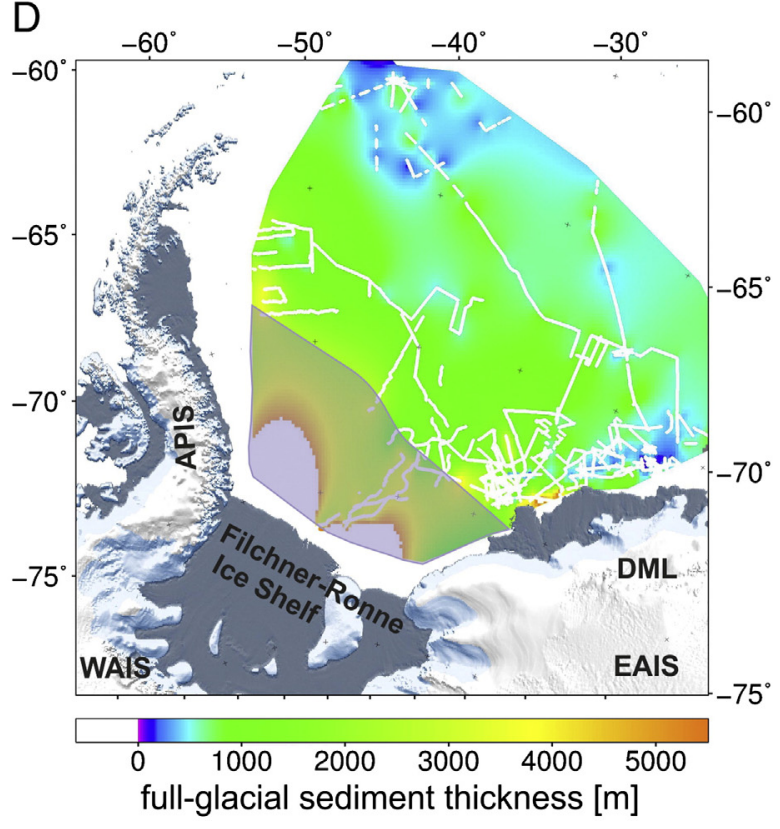

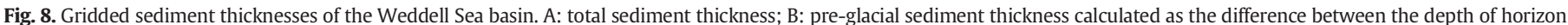

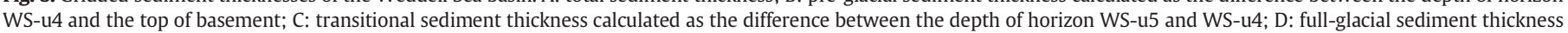
calculated as the difference between the depth of the seafloor and horizon WS-u5. The masked areas are assumptions based on seismic refraction experiments.

he Cretaceous and early Cenozoic global 'greenhouse' climate (e.g. Zachos et al., 2008), we can rule out any role for glaciallycontrolled transport processes. During late Eocene times, temperate alpine-style glacial conditions have been suggested for the northern Antarctic Peninsula region by analyses of shallow sediment drill cores from the northwestern Weddell Sea shelf (Smith and Anderson, 2010; Anderson et al., 2011), but it can be expected that their contribution to the pre-glacial sediments in the entire Weddell Sea basin is relatively small (Fig. 9A).

It can therefore be assumed that the bulk of the sediment transport was carried out by continental-scale river systems, transporting sediments from the Antarctic interior through the Filchner-Ronne rift basin and depositing most of it in the evolving southern Weddell Sea (Weber et al., 1994; Michels et al., 2002) (Fig. 11). It can be speculated that erosion of the subduction-related orogen of the Antarctic Peninsula supplied sediments to the western Weddell Sea margin.

\subsection{Transitional phase}

In our stratigraphic age model, deposition of the transitional unit begins at the Eocene-Oligocene boundary ( $34 \mathrm{Ma})$ in the southern Weddell Sea and between 10 and $15.5 \mathrm{Ma}$ in the northwestern Weddell Sea. Compared to the pre-glacial unit, the sediment thickness is relatively thin, but it accumulated at much higher rates (up to $140 \mathrm{~m} / \mathrm{Myr}$ ), particularly in the southern Weddell Sea depocenter (Fig. 8C, B). The change of sedimentation rate can be related to marked changes in transport and depositional environment, for instance the onset of coast-proximal ice sheet grounding that would increase the quantity 

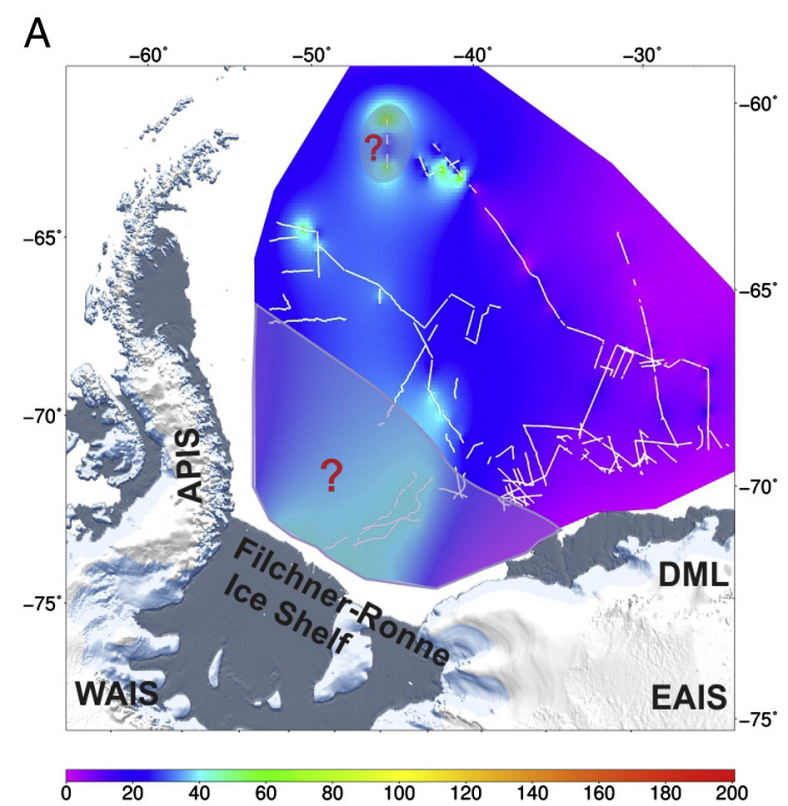

Pre-glacial-sedimentation-rates [m/my]
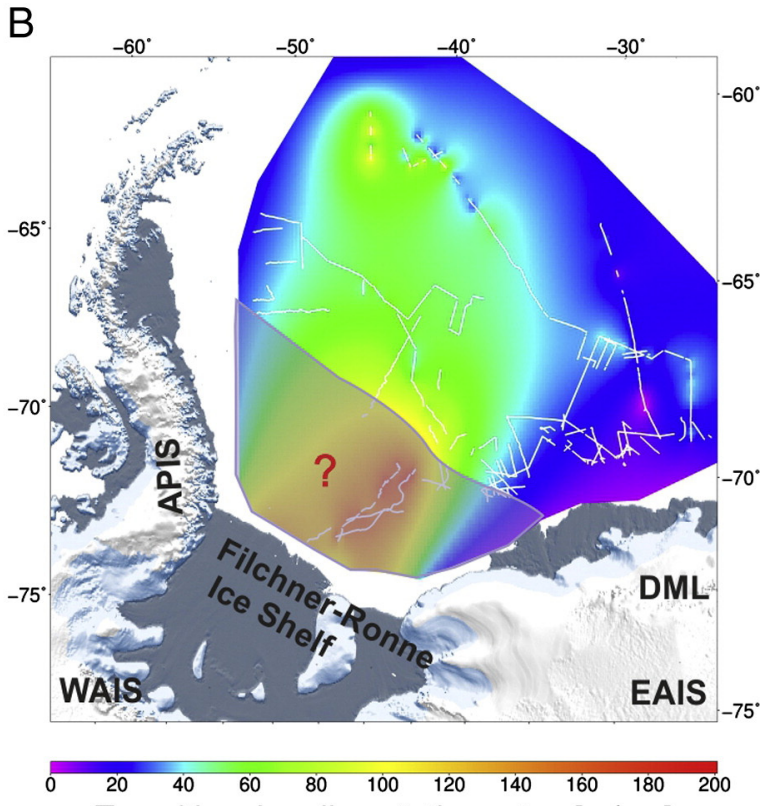

Transitional-sedimentation-rates [m/my]
C

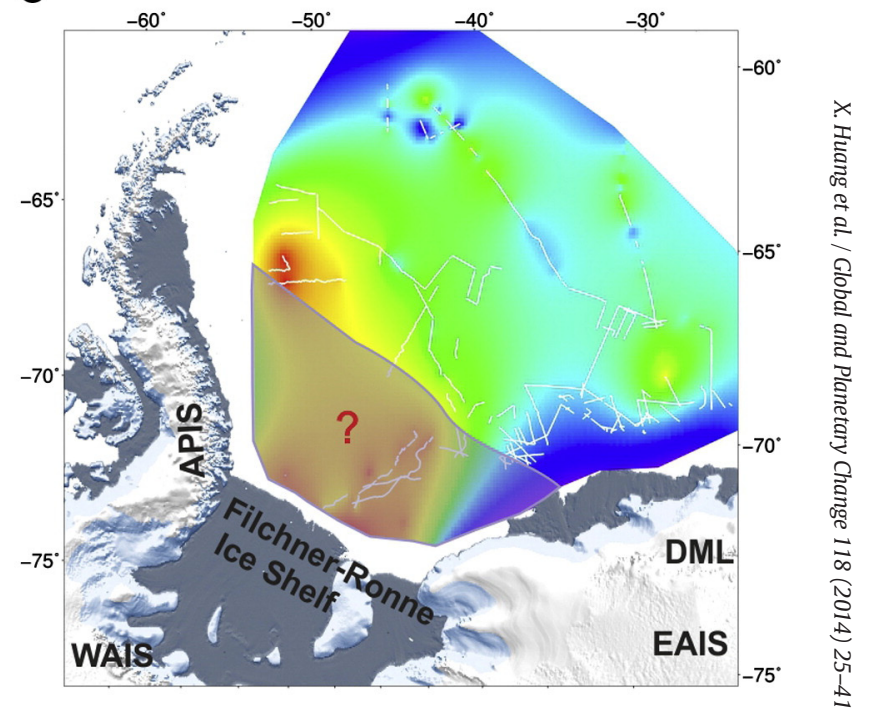

Full-glacial-sedimentation-rates $[\mathrm{m} / \mathrm{my}]$

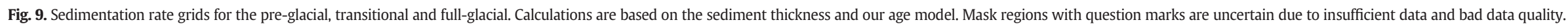




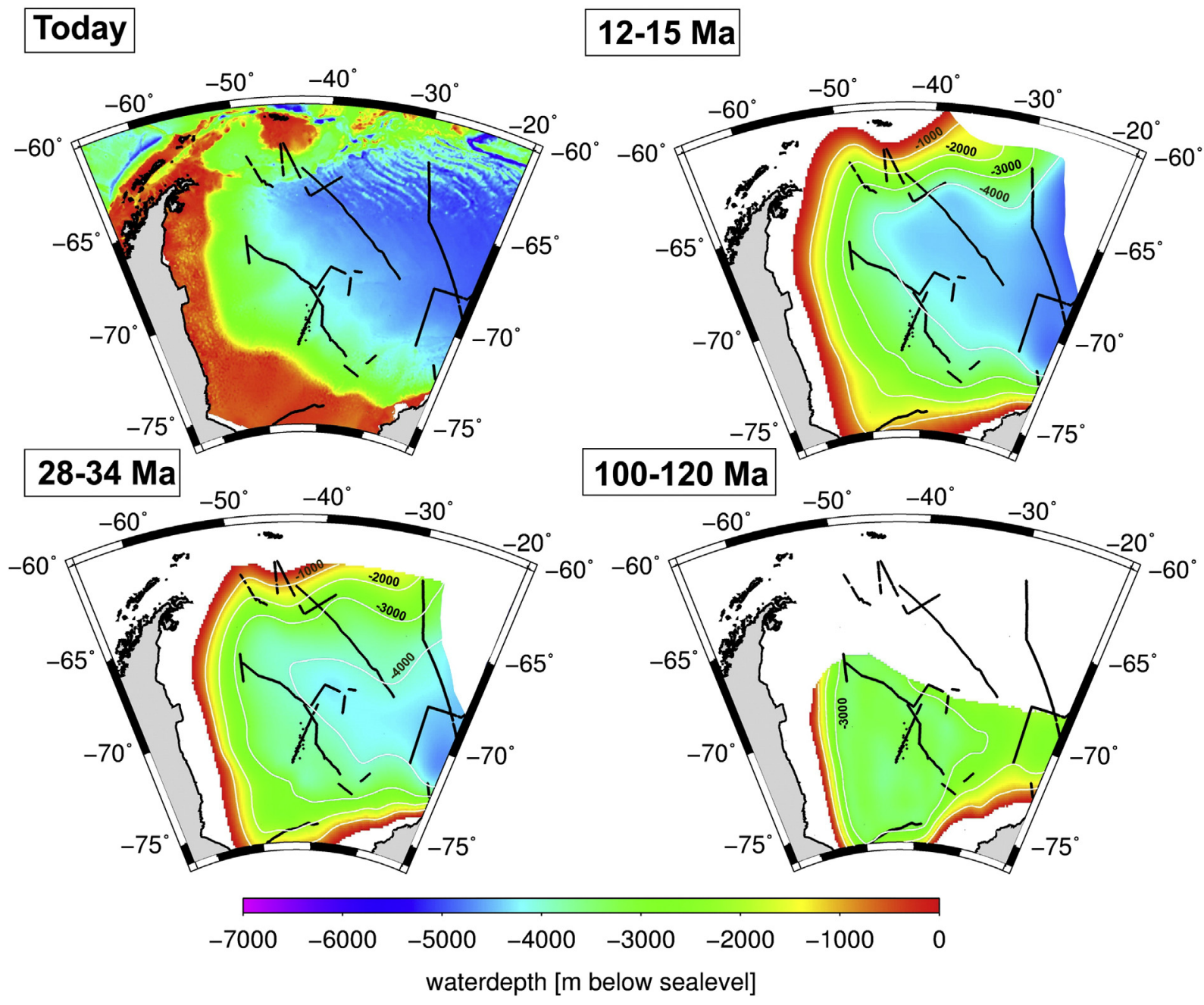

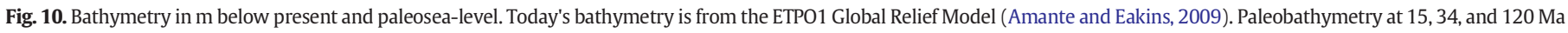
is calculated in this study. The coastline plotted at $120 \mathrm{Ma}$ is to give a general orientation, not the true coastline at that time.

of sediments delivered into the basin. The shift to a cool-temperate climate with perennial sea-ice in Antarctica is evident in the global deep-sea oxygen isotope signature at the Eocene-Oligocene boundary (Zachos et al., 2001, 2008; Liu et al., 2009). Gravel- and pebble-grade IRDs have been observed in middle to lower Oligocene sediments of ODP Leg 113 Site 693 (Barker et al., 1988). This implies that glaciers were grounded close to the coast or on the inner shelf at that time (Barker and Thomas, 2004).

Sediments of the transitional unit are about 1-km thick off the eastern Antarctic Peninsula margin and decrease to $0.5 \mathrm{~km}$ thickness in the northwestern Weddell Sea (Fig. 8C). Our calculations show that sedimentation rates are in the range of $60-100 \mathrm{~m} / \mathrm{Myr}$ (Fig. 9C) and compared to those determined for the region by Maldonado et al. (2003) (70-108 m/Myr) and Lindeque et al. (2013) (110 m/Myr). The variable sedimentation rates and thicknesses during the transitional phase may be related to varying onset times for the various sectors of the Antarctic Peninsula Ice Sheet. Anderson et al. (2011) and Smith and Anderson (2010) argued for the presence of local glaciers and ice caps during the middle Eocene-early Oligocene (49-32 Ma) and early Oligocene at the northern Antarctica Peninsula. We see no obvious evidence to conclude that a major WAIS was grounded on the inner shelf of the Weddell Sea in the Oligocene. What if, we would expect to have a significant higher sedimentation rate than we observe as well as erosional features occurred during the deposition processes. This confirms earlier studies showing that continental ice of West Antarctica consisted of isolated ice caps in the Oligocene that amalgamated and advanced onto the continental shelves not earlier than at Late Miocene times (Anderson et al., 2011).

The development of the Antarctic Circumpolar Current (ACC) would not only have enhanced Antarctic ice sheet growth but also changed the way that the Weddell Gyre, which may have affected the sediment deposition and erosion in the Weddell Sea, interacted with the global ocean. In particular, Antarctic Bottom Water (AABW) and Warm Saline Deep Water, as shown by Diester-Haass and Zahn (1996), may have been integrated to the general ocean circulation during the transitional regime (Fig. 11).

\subsection{Full-glacial phase}

The full-glacial unit of the Weddell Sea has been deposited since the middle Miocene (15 Ma) according to our stratigraphic model. A large amount of sediments (up to $5 \mathrm{~km}$ thickness) were deposited (Fig. 8D) at very high sedimentation rates (up to $180 \mathrm{~m} / \mathrm{Myr}$ ) in the main depocenter in front of the Filchner-Ronne Ice Shelf. The resulting Crary Fan is not mapped completely in the full glacial unit due to the limited seismic data in the southern Weddell Sea. Despite the lack of data, it is evident that the fan was formed by glacial sediments supplied from western Dronning Maud Land as inferred in earlier studies. Kuvaas and Kristoffersen (1991) argue that this would have occurred after the EAIS advanced to the coastline, triggering enormous down-slope transport to the continental rise in the middle Miocene (Bart et al., 1999). The time since the middle Miocene is the period in which the major 


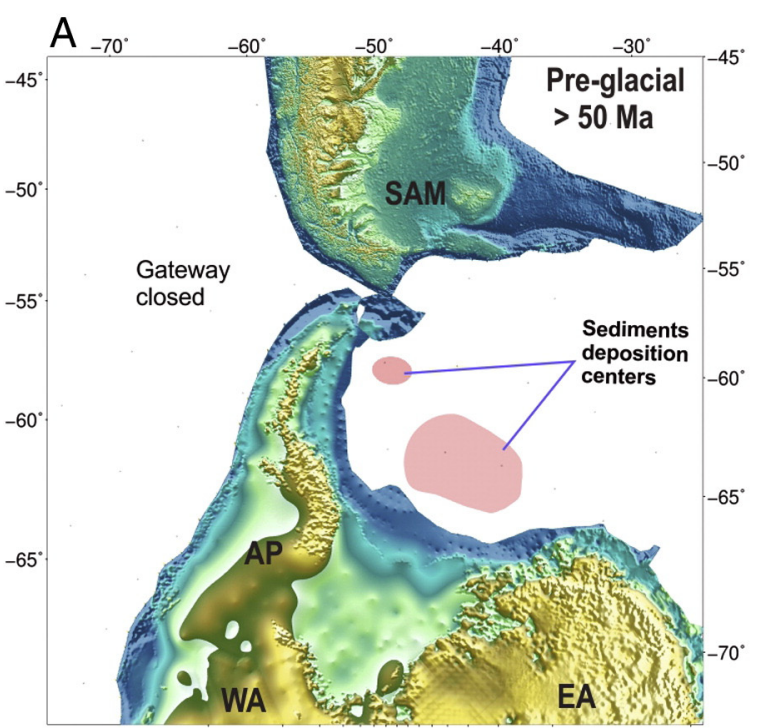

$-6000-5000-4000-3000-2000-1000 \quad 0 \quad 1000 \quad 2000 \quad 3000 \quad 4000$
B -70

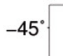

$-45^{\circ}$

$-50^{\circ}$

$-55^{\circ}$

$-$

$-60^{\circ}$

$-65$
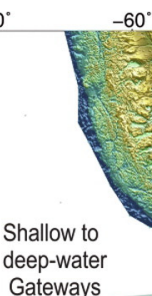

Gateways

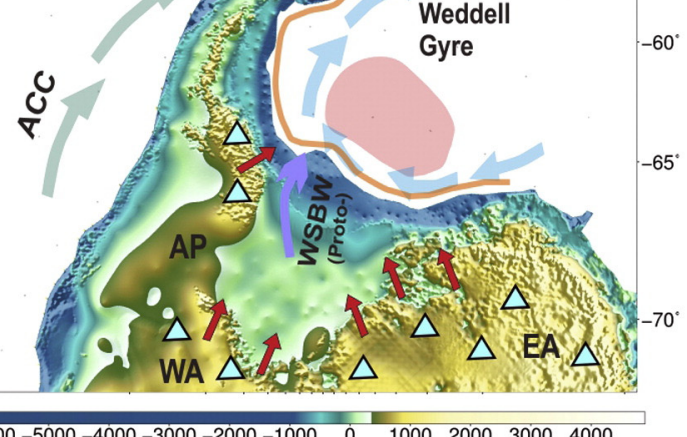

C

Early transitional

34-28 $\mathrm{Ma}$

$-50^{\circ}$

$-60$

$-6000-5000-4000-3000-2000-1000 \quad 0 \quad 1000200030004000$ $-65^{\circ}$

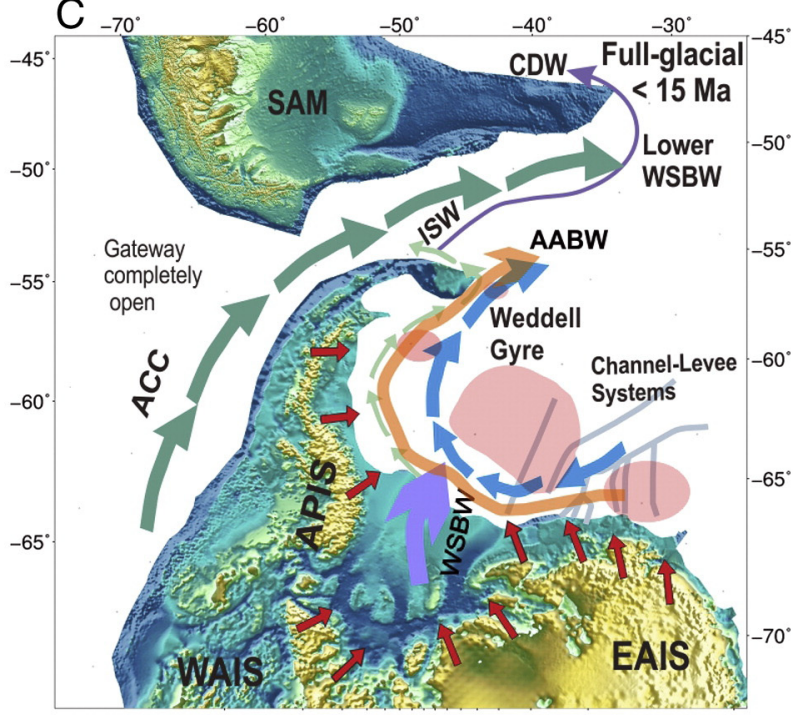

$-6000-5000-4000-3000-2000-1000 \quad 0 \quad 1000200030004000$

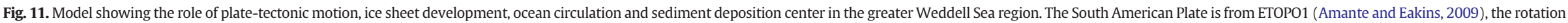

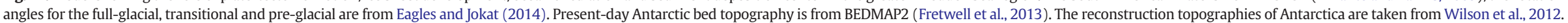

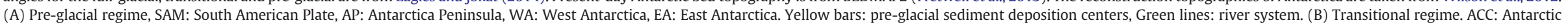
Circumpolar Current. Triangles: ice-caps. Red arrow: the direction of ice movement. (C) Full-glacial regime. 
Antarctic ice sheets have been built (e.g., Lear et al., 2000; Zachos et al., 2001; Shevenell et al., 2004) and played a dominant role in sedimentation processes. The first significant observations of IRDs and turbidite units are reported from the middle Miocene of ODP Sites 693 and 694, indicating the presence of ice sheets grounding on the shelves and generating a large influx of sediments to the Weddell Sea basin (Barker et al., 1988; Kennett, 1990).

Our data reveal another depocenter off the western Weddell Sea margin east of the Antarctica Peninsula with about $3 \mathrm{~km}$ sediment thickness and relatively high sedimentation rates (Figs. 8D, 9C). Shelf sediment progradation observed in seismic profiles east of the Antarctic Peninsula and depositional lobes in the northwestern Weddell Sea imply phases of an APIS advancing to the outer shelf (Barker and Camerlenghi, 2002; Bart et al., 2005). From this marine evidence, it is possible to infer that significant ice sheet growth in West Antarctica and on the Antarctic Peninsula occurred and impacted the sedimentation during the full-glacial time in the Weddell Sea region.

Contourite studies have identified ocean-bottom current directions around the Antarctic Peninsula and at the southern continental margin of the Weddell Sea (Michels et al., 2001; Maldonado et al., 2005). They also infer increased bottom current intensity along the entire Antarctic margin of the Weddell Sea in the period from $\sim 15$ to $5 \mathrm{Ma}$. The Weddell Gyre and a fully developed ACC interacted with other water masses to influence the deposition pattern (Fig. 11). The distribution of contourite drifts was mainly controlled by the physiography of the basin and bottom current flow directions (Maldonado et al., 2005). As illustrated by Fig. 6, abundant sediment drifts and channel-levee systems occur on the continental margin in the full-glacial unit. Younger sediments are mostly drift deposits that reach a thickness of more than $1 \mathrm{~km}$ and accumulated at rates of more than $80 \mathrm{~m} / \mathrm{Myr}$, particularly during the late Miocene (Figs. 5, 9C). These drift bodies developed during the transport of sediments by a combination of contour currents and/or turbidity flows (Michels et al., 2001; Uenzelmann-Neben, 2006), fed by an abundance of glacial sediments brought to the basin margin cycles of ice sheet advanced and retreat.

\subsection{Paleobathymetry}

Possible sources of error in the paleobathymetric estimates are uncertainties in the modeled lithospheric thickness, stretching factor, porosity-depth relationship, and distributions of crustal nature and age. Seismic data from the edge of the Filchner-Ronne Ice Shelf suggest a continental crustal stretching factor between 1.5 and 3.0 (Hübscher et al., 1996; Jokat et al., 1996). Following König and Jokat (2006), we use a relatively large stretching factor of 2.5 for the rifted continental crust and lithosphere, which they adopted for reconstructing the initial position of the Antarctic Peninsula with respect to East Antarctica at the Filchner-Ronne Ice Shelf. Stretching factors of 1.5-3.0 lead to differences of $0.2-2.0 \mathrm{~km}$ in thermal subsidence. A large source of uncertainty consists of the lack of knowledge on the extent of the continent-ocean transition of the Weddell Sea embayment. We used the simplified continent-ocean transition (COT) proposed by König and Jokat (2006) and applied a simple boundary between regions modeled with continental and oceanic thermal subsidence. For instance, at $120 \mathrm{Ma}$, the effect of thermal subsidence varies from $1.6 \mathrm{~km}$ to $2.5 \mathrm{~km}$ based on the oceanic crust model. However, the continental crustal subsidence model results in about $3 \mathrm{~km}$ sinking close to the COT, which means that the relative error can be as high as $95 \%$.

Available drill sites in the Weddell Sea basin only provide local porosity-depth relationships to a maximum sedimentary penetration depth of $700 \mathrm{~m}$. Our adoption of these porosities for the entire basin is an oversimplification. For instance, as Fig. 3 shows if we apply a top porosity $\phi_{0}$ and constant c as $50 \%, 0.0005$ or $80 \%, 0.0007$ instead of $70 \%$, 0.0007 , which was obtained from ODP Leg 113 , this leads to relative errors around $-30 \%$ and $+16 \%$ of $\phi_{0}=70 \%$ and $-33 \%$ for $\mathrm{c}=0.0007$.
Further sources of uncertainty arise from processes and parameters that we have not taken into account. Oceanic crustal thickness variations lead to areas of shallower and deeper bathymetry. Long wavelength changes result from the transmission of viscous stresses to the lithosphere from the underlying mantle. This dynamic topography may affect large areas with amplitudes of $\pm 1 \mathrm{~km}$ (Steinberger et al., 2001). Negative dynamic topography accompanies subduction, which was ongoing along the Antarctic Peninsula with an eastward subducting plate throughout Cretaceous and Cenozoic times. Positive dynamic topography accompanies the action of mantle plumes, which are thought to have accompanied the earliest stages of breakup in the Weddell Sea and to have affected the Maud Rise region in Albian times.

However, by taking into account all presently available geophysical and geological information and considering the existing large uncertainties, we are confident to deliver a first estimate of the paleobathymetric evolution of the Weddell basin, which will improve the testing of paleoceanographic and paleoclimatic scenarios through model simulations.

\section{Conclusions}

1. We extended existing local and sub-regional stratigraphic models to the entire Weddell Sea basin. Two seismic unconformities (WS-u4, WS-u5) and three seismic units (pre-glacial, transitional, full glacial) were mapped and served as a base to calculate for the first time basin-wide grids of sediment depths, thicknesses, rates and paleobathymetries.

2. The distribution of the total sediment thickness shows a decreasing trend northward. The maximum sediment thickness of up to $12 \mathrm{~km}$ is found in the southern Weddell Sea in front of the Filchner-Ronne Ice Shelf.

3. The pre-glacial unit has the thickest sediments owing to its long sedimentation period of $80-100 \mathrm{~m} / \mathrm{Myr}$, but was deposited with a relatively low rate. The tectonic evolution and seafloor spreading history of the Weddell Sea interacted with terrigenous sediment supply processes to control its distribution.

4. The transitional unit accumulated at a relatively high sedimentation rate. Its thickness varies in the range of $0-3 \mathrm{~km}$. A relatively strong sediment supply from a growing EAIS grounded to the coast or even inner shelf could be the main contributor to sedimentation on the continental rise.

5. The high sedimentation rate at the full glacial period generated depocenters near the margins of the southern, southeastern and western Weddell Sea. Here, the maximum sediment thickness is 4-5 $\mathrm{km}$ for this period. Sedimentation rates varied from 0 to $200 \mathrm{~m} / \mathrm{Myr}$. The large amount of sediments and their deposition at high sedimentation rates in the southern Weddell Sea imply an increase of glacial advances of grounded EAIS, WAIS and APIS to the middle or outer shelf since the middle Miocene. Large sedimentary drifts and channel-levee complexes are abundant close to the continental margin, suggesting turbidity currents and other mass-flow processes redistributing the sediments.

6. We derived a grid series of the paleobathymetric evolution of the Weddell Sea basin for $120 \mathrm{Ma}, 34 \mathrm{Ma}$ and $15 \mathrm{Ma}$, which will improve the testing of paleoceanographic and paleoclimatic scenarios through model simulations.

\section{Acknowledgments}

The authors would like to thank the masters, crews and seismic teams of the many ship expeditions to the Weddell Sea who made the acquisition of the data used in this study possible. The British Antarctic Survey (BAS), the German Federal Institute of Geosciences and Resources (BGR) as well as research institutes in Norway and Spain are gratefully acknowledged for their contribution of the used seismic data to the Antarctic Seismic Data Library System (SDLS). We used the 
GMT graphics software (Smith and Wessel, 1990) for gridding routines and map productions. Many thanks to Graeme Eagles for his careful reading of the manuscript before submission. X.H. has been receiving a PhD scholarship from the Chinese Scholarship Council. This study has primarily been supported through institutional funds of the Alfred Wegener Institute through Work Package 3.2 of its research program PACES.

\section{References}

Amante, C., Eakins, B.W., 2009. ETOPO1 1 Arc-Minute Global Relief Model: procedures, data sources and analysis. NOAA Technical Memorandum NESDIS NGDC-24 (March, 19 pp.)

Anderson, J.B., 1999. Antarctic Marine Geology. Cambridge University Press (289 pp.).

Anderson, John B., Andrews, John T., 1999. Radiocarbon constrains on ice sheet advance and retreat in the Weddell Sea, Antarctica. Geology 27 (2), 179-182. http://dx.doi. org/10.1130/0091-7613(1999)027<0179:RCOISA >2.3.CO;2.

Anderson, J.B., Wellner, J.S. (Eds.), 2011. Tectonic, Climatic, and Cryospheric Evolution of the Antarctic Peninsula. American Geophysical Union, Washington, D. C. http://dx. doi.org/10.1029/SP063 (218 pp.).

Anderson, J.B., Warny, S., Askin, R., Wellner, J., Bohaty, S., Smith, T., 2011. Cenozoic cryosphere expansion and the demise of Antarctica's last refugium. Proc. Natl. Acad. Sci. 108, 11299-11726

Arndt, J.E., Schenke, H.W., Jakobsson, M., Nitsche, F., Buys, G., Goleby, B., Rebesco, M., Bohoyo, F., Hong, J.K., Black, J., Greku, R., Udintsev, G., Barrios, F., Reynoso-Peralta, W., Morishita, T., Wigley, R., 2013. The International Bathymetric Chart of the Southern Ocean (IBCSO) version 1.0 - a new bathymetric compilation covering circumAntarctic waters. Geophys. Res. Lett. http://dx.doi.org/10.1002/grl.50413.

Barker, P.F., Camerlenghi, A., 2002. Glacial history of the Antarctic Peninsula from Pacific margin sediments. In: Barker, P.F., Camerlenghi, A., Acton, G.D., Ramsay, A.T.S. (Eds.), Proceedings of the Ocean Drilling Program. Scientific Results, 178. Ocean Drilling Program, College Station, TX, 77845-9547, USA, pp. 1-40.

Barker, P.F., Thomas, E., 2004. Origin, signature and palaeoclimate influence of the Antarctic Circumpolar Current. Earth Sci. Rev. 55, 1-39. http://dx.doi.org/10.1016/j. earscirev.2003.10.003.

Barker, P.F., Kennett, J.P., et al., 1988. Proceedings of the Ocean Drilling Program, scientific results Leg 113. Ocean Drill. Program 774. http://dx.doi.org/10.2973/odp.proc.ir.113. 1988.

Bart, P.J., Batist, D.E., Jokat, W., 1999. Interglacial collapse of Crary Trough Mouth Fan, Weddell Sea, Antarctica: implications for Antarctic glacial history analysis. J. Sediment Res. 69 (6), 1276-1289.

Bart, P.J., Egan, D.E., Warny, S.A., 2005. Direct constraints on Antarctic Peninsula Ice Sheet grounding events between 5.12 and 7.94 Ma. J. Geophys. Res. 110, F04008. http://dx. doi.org/10.1029/2004JF000254.

Bohoyo, F., Galindo-Zaldívar, J., Jabaloy, A., Maldonado, A., Rodríguez-Fernández, J., Schreider, A., Suriñach, E., 2007. Extensional deformation and development of deep basins associated with the sinistral transcurrent fault zone of the Scotia-Antarctic plate boundary. Geol. Soc. Lond., Spec. Publ. 290, 203-217. http://dx.doi.org/10. 1144/SP290.6.

Brown, B., Gaina, C., Mueller, R.D., 2006. Circum-Antarctic palaeobathymetry: illustrated examples from Cenozoic to recent times. Palaeogeogr. Palaeoclimatol. Palaeoecol. 231, 158-168. http://dx.doi.org/10.1016/j.palaeo.2005.07.033.

Dalziel, I.W.D., 2007. The Ellsworth Mountains: critical and enduringly enigmatic. In: Copper, A.K., Raymond, C.F. (Eds.), Antarctica: A Keystone in a Changing WorldOnline Proceedings of the 1-th ISAES. USGS Open-File Report 2007-1047, Short Research Paper 004. http://dx.doi.org/10.3133/of2007-1047.srp004 (5 pp.).

Dalziel, I.W.D., Grunow, A., 1992. Late Gondwanide tectonic rotations within Gondwanaland. Tectonics 11, 603-606.

DeConto, R.D., Pollard, D., 2003a. Rapid Cenozoic glaciation of Antarctica triggered by declining atmospheric $\mathrm{CO}_{2}$. Nature 421, 245-249.

DeConto, R.D., Pollard, D., 2003b. A coupled climate-ice sheet modeling approach to the early Cenozoic history of the Antarctic ice sheet. Palaeogeogr. Palaeoclimatol. Palaeoecol. 198, 39-52.

Diester-Haass, L., Zahn, R., 1996. The Eocene-Oligocene transition in the Southern Ocean: history of water masses, circulation, and biological productivity inferred from high resolution records of stable isotopes and benthic foraminiferal abundances (ODP Site 689). Geology 26, 163-166.

Eagles, G., Jokat, W., 2014. Plate tectonic reconstructions for studies in Drake Passage. Tectonophysics 611, 28-50. http://dx.doi.org/10.1016/j.tecto.2013.11.021.

Eagles, G., Livermore, R.A., 2002. Opening history of Powell Basin, Antarctic Peninsula. Mar. Pet. Geol. 185 (3-4), 195-205. http://dx.doi.org/10.1016/S0025-3227(02)00191-3.

Foldvik, A., Gammelsrød, T., Østerhus, S., Fahrbach, E., Rohardt, G., Schro“der, M., Nicholls, K., Padman, L., Woodgate, R., 2004. Ice Shelf Water overflow and bottom water formation in the southern Weddell Sea. J. Geophys. Res. 109, C02015. http://dx.doi. org/10.1029/2003JC002008.

Fretwell, P., Pritchard, H., Vaughan, D.G., Bamber, J.L., Barrand, N., Bell, R., Bianchi, C., Bingham, R., Blankenship, D.D., Casassa, G., Catania, G., Callens, D., Conway, H., Cook, A., Corr, H.F.J., Damaske, D., Damm, V., Ferraccioli, F., Forsberg, R., Fujita, S., Furukawa, T., Gogineni, P., Griggs, J., Hamilton, G., Hindmarsh, R., Holmlund, P., Holt, J., Jacobel, R., Jenkins, A., Jokat, W., Jordan, T., King, E.C., Krabill, W., Riger-Kusk, M., Tinto, K., Langley, K., Leitchenkov, G., Luyendyk, B.P., Matsuoka, K., Nixdorf, U., Nogi, Y., Nost, O., Popov, S., Rignot, E., Rippin, D., Riviera, A., Ross, N., Siegert, M.J., Shibuya, K., Smith, A., Steinhage, D., Studinger, M., Sun, B., Thomas, R., Tabacco, I. Welch, B., Young, D., Xiangbin, C., Zirizzotti, A., 2013. Bedmap2: improved ice bed, surface and thickness datasets for Antarctica. Cryosphere 7, 375-393. http://dx.doi. org/10.5194/tc-7-375-2013.

Ghidella, M.E., Ya'ñez, G., LaBrecque, J.L., 2002. Revised tectonic implications for the magnetic anomalies of the western Weddell Sea. Tectonophysics 347, 65-86. http://dx.doi.org/10.1016/S0040-1951(01)00238-4.

Haugland, K., Kristoffersen, Y., Velde, A., 1985. Seismic investigations in the Weddell Sea embayment. Tectonophysics 114, 293-313. http://dx.doi.org/10.1016/00401951(85)900018-6.

Hübscher, C., 1994. Krustenstrukturen und Verlauf des Kontinentalrandes im WeddellMeer/Antarktis. Ber. Polarforsch. 147, 233.

Hübscher, C., Jokat, W., Miller, H., 1996. Structure and origin of southern Weddell Sea crust: results and implications. In: Storey, B.C., King, E.C., Livermore, R.A. (Eds.), Weddell Sea Tectonics and Gondwana Break-up. Geol. Soc., London, Spec Publ., 108, pp. 201-212.

Hübscher, C., Jokat, W., King, E., Kudryavtzev, G., Leitchenkov, G., 1998. The Weddell Sea basin between Nerkner Island and Antarcti Peninsula. Terra Antarct. 5 (195-198).

Jokat, W., Hübscher, C., Meyer, U., Oszko, L., Schöne, T., Versteeg, W., Miller, H., 1996. The continental margin off East Antarctica between 10 W and 30 W. In: Storey, B.C., King, E.C., Livermore, R.A. (Eds.), Weddell Sea Tectonics and Gondwana Break up. Geol. Soc. Spec. Publ., 108, pp. 129-141.

Jokat, W., Boebel, T., König, M., Meyer, U., 2003. Timing and geometry of early Gondwana breakup. J. Geophys. Res. 108 (B9), 2428. http://dx.doi.org/10.1029/2002JB001802.

Kennett, J.P.a.B., P,.F., 1990. Climatic and oceanographic developments in the Weddel Sea, Antarctica, since the latest Cretaceous: An ocean-drilling Program. Ocean Drill. Program Sci. Results 113, 865-880.

King, E.C., 2000. The crustal structure and sedimentation of the Weddell Sea embayment: implication for Gondwana reconstructions. Tectonophysics 327, 195-212.

König, M., Jokat, W., 2006. The Mesozoic breakup of the Weddell Sea. J. Geophys. Res. 111 B12102. http://dx.doi.org/10.1029/2005JB004035.

König, M., Jokat, W., 2010. Advanced insights into magmatism and volcanism of the Mozambique Ridge and Mozambique Basin in the view of new potential field data. Geophys. J. Int. 180, 158-180. http://dx.doi.org/10.1111/j.1365-246X.2009.04433.x.

Kudryavtzev, G.A., Smirnova, E.A., Schumilov, V.A., Poselov, V.A., 1987. Deep structure of the earth crust in the southern part of the Weddell Sea (by data of the DSS line (in Russian). In: Ivanov, V.L., Grikurov, G.E. (Eds.), The Geological and Geophysical Research in Antarctica. Sevmorgeologia, Leningrad, pp. 99-108.

Kuvaas, B., Kristoffersen, Y., 1991. The Crary Fan: a trough-mouth fan on the Weddell Sea Continental Margin, Antarctica. Mar. Geol. 97, 345-362. http://dx.doi.org/10.1016/ 0025-3227(91)90125-N.

Lawver, L.A., Gahagan, L.M., 1998. Opening of Drake Passage and its impact on Cenozoic ocean circulation. In: Crowley, T.J., Burke, K.C. (Eds.), Tectonic Boundary Conditions for Climate Reconstructions. Oxford Univ. Press, New York, pp. 212-223.

Lawver, L.A., Royer, J.-Y., Sandwell, D.T., Scotese, C.R., 1991. Crustal development: Gondwana break-up - evolution of the Antarctic continental margins. In: Thompson, M.R.A. Crame, J.A., Thompson, J. (Eds.), Geological Evolution of Antarctica. Cambridge Univ pp. 533-540.

Lear, C.H., Elderfield, H., Wilson, P.A., 2000. Cenozoic deep-sea temperatures and global ice volumes from $\mathrm{Mg} / \mathrm{Ca}$ in benthic foraminiferal calcite. Science 287, 269-272. http://dx.doi.org/10.1126/science.287.5451.269.

Leitchenkov, G., Guseva, J., Gandyukhin, V., Grikurov, G., Kristoffersen, Y., Sand, M. Golynsky, A., Aleshkova, N., 2008. Crustal structure and tectonic provinces of the Riiser-Larsen Sea are (East Antarctica): results of Geophysical studies. Mar. Geophys. Res. 29, 135-158. http://dx.doi.org/10.1007/s11011-008-9051-z.

Lindeque, A., Martin, Y., Gohl, K., Maldonado, A., 2013. Deep sea pre-glacial to glacial sedimentation in the Weddell Sea and southern Scotia Sea from a cross-basin seismic transect. Mar. Geol. 336, 61-83. http://dx.doi.org/10.1016/j.margeo.2012.11.004

Liu, Z., Pagani, M., Zinniker, D., Deconto, R., Brinkhuis, H., Shah, R.S., Leckie, M., Pearson, A. 2009. Global cooling during the Eocene-Oligocene climate transition. Science 323, 1187-1190. http://dx.doi.org/10.1126/science.1166368.

Livermore, R.A., Hunter, R.J., 1996. Mesozoic seafloor spreading in the southern Weddel Sea. In: Storey, B.C., King, E.C., Livermore, R.A. (Eds.), Weddell Sea Tectonics and Gondwana Break-up. Geological Society of London Special Publications, 108. The Geological Society, London, pp. 227-241.

Livermore, R.A., Woollett, R.W., 1993. Seafloor spreading in the Weddell Sea and southwest Atlantic since the Late Cretaceous. Earth Planet. Sci. Lett. 117, 475-495.

Maldonado, A., Barnolas, A., Bohoyo, F., Galindo-Zaldívar, J., Hernández-Molina, J., Lobo, F. Rodríguez-Fernández, J., Somoza, L., Vázquez, J.T., 2003. Contourite deposits in the central Scotia Sea: the importance of the Antarctic Circumpolar Current and Weddell Gyre flows. Palaeogeogr. Palaeoclimatol. Palaeoecol. 198, 187-221. http://dx.doi.org/ 10.1016/S0031-0182(03)00401-2.

Maldonado, A., Barnolas, A., Bohoyo, F., Escutia, C. Galindo-Zaldivar, J. Hernández-Molina, F.J., Jabaloy, A., Lobo, F.J., Nelson, C.H., Rodríguez-Fernández, J., Somoza, L., Vázquez, J.T., 2005. Miocene to recent contourite drifts development in the northern Weddell Sea (Antarctica). Glob. Planet. Change 45, 99-129. http://dx. doi.org/10.1016/j.gloplacha.2004.09.013.

Maldonado, A., Bohoyo, F., Galindo-Zaldívar, J., Hernández-Molina, F.J., Lobo, F.J., Shreyder, A.A., Suriñach, E., 2007. Early opening of Drake Passage: regional seismic stratigraphy and paleoceanographic implications. In: Cooper, A.K., Raymond, C.R., et al. (Eds.) Antarctica: A Keystone in a Changing World. Extended Abstract EA57, Online Proceedings of the 10th International Symposium on Antarctic Sciences (ISAES). USGS Open-File Report (http://pubs.usgs.gov/of/2007/1047/ea/of2007-1047ea057.pdf).

McKenzie, D.P., 1978. Some remarks on the development of sedimentary basins. Earth Planet. Sci. Lett. 40, 25-32.

Michels, K.H., Rogenhagen, J., Kuhn, G., 2001. Recognition of contour-current influence in mixed contourite-turbidite sequences of the western Weddell Sea, Antarctica. Mar. Geophys. Res. 22, 465-485. http://dx.doi.org/10.1023/A:1016303817273. 
Michels, K.H., Kuhn, G., Hillenbrand, C.-D., Diekmann, B., Fütterer, D.K., Grobe, H. Uenzelmann-Neben, G., 2002. The southern Weddell Sea: combined contouriteturbidites sedimentation at the southeastern margin of the Weddell Gyre. In: Stow D.A.V., Pudsey, C., Howe, J.C., Faugères, J.C., Viana, A.R. (Eds.), Geological Society of London, Memoirs, 22, pp. 305-323. http://dx.doi.org/10.1144/GSL.MEM. 2002.022 01.32 .

Miller, K., 2005. The Phanerozoic record of global sea-level change. Science 310. http://dx. doi.org/10.1126/science.1116412.

Miller, H., Henriet, J.P., Kaul, N., Moons, A., 1990. A fine-scale stratigraphy of the eastern margin of the Weddell Sea. In: Bleil, U., Thiede, J. (Eds.), Geological History of the Polar Oceans: Arctic Versus Antarctic. Kluwer Academic Publishers, pp. 131-161. http://dx.doi.org/10.1007/978-94-009-2029-3_8.

Naish, T.R., Woolfe, K.J., Barrett, P.J., Wilson, G.S., Atkins, C., Bohaty, S.M., Buckner, C.J., Claps, M., Davey, F.J., Dunbar, G.B., Dunn, A.G., Fielding, C.R., Florindo, F., Hannah, M.J., Harwood, D.M., Henrys, S.A., Krissek, L.A., Lavelle, M.A., van der Meer, J., McIntosh, W.C., Niessen, F., Passchier, S., Powell, R.D., Roberts, A.P., Sagnotti, L. Scherer, R.P., Strong, C.P., Talarico, F., Verosub, K.L., Villa, G., Watkins, D.K. Webb, P.N., Wonik, T., 2001. Orbitally induced oscillations in the East Antarctic ice sheet at the Oligocene/Miocene boundary. Nature 413, 719-723.

Naish, T., Powell, R., Levy, R., Wilson, G., Scherer, R., Talarico, F., Krissek, L., Niessen, F., Pompilio, M., Wilson, T., Carter, L., DeConto, R., Huybers, P., McKay, R., Pollard, D., Ross, J., Winter, D., Barrett, P., Browne, G., Cody, R., Cowan, E., Crampton, J., Dunbar, G., Dunbar, N., Florindo, F., Gebhardt, C., Graham, I., Hannah, M., Hansaraj, D., Harwood, D., Helling, D., Henrys, S., Hinnov, L., Kuhn, G., Kyle, P., Läufer, A., Maffioli, P., Magens, D., Mandernack, K., McIntosh, W., Millan, C., Morin, R., Ohneiser, C., Paulsen, T., Persico, D., Raine, I., Reed, J., Riesselman, C., Sagnotti, L., Schmitt, D., Sjunneskog, C., Strong, P., Taviani, M., Vogel, S., Wilch, T., Williams, T., 2009. Obliquitypaced Pliocene West Antarctic ice sheet oscillations. Nature 458 (7236), 322-328.

Orsi, A., Johnson, G., Bullister, J., 1999. Circulation, mixing, and production of Antarctic Bottom Water. Prog. Oceanogr. 43, 55-109.

Parsons, B., Sclater, J.G., 1977. An analysis of the variation of ocean floor bathymetry and heat flow with age. J. Geophys. Res. 82, 803-827.

Passchier, S., Bohaty, S.M., Jiménez-Espejo, F., Pross, J., Röhl, U., van de Flierdt, T., Escutia, C., Brinkhuis, H., 2013. Early Eocene to middle Miocene cooling and aridification of East Antarctica. Geochem. Geophys. Geosyst. 14 (5), 1399-1410. http://dx.doi.org/10.1002/ ggge.20106.

Pollard, D., DeConto, R.M., 2005. Hysteresis in Cenozoic Antarctic ice sheet variations. Glob. Planet. Change 45, 9-21. http://dx.doi.org/10.1016/j.gloplacha.2004.09.011.

Pollard, D., DeConto, R.M., 2009. Modelling West Antarctic ice sheet growth and collapse through the past five million years. Nature 458, 320-323. http://dx.doi.org/10.1038/ nature07809.

Rogenhagen, J., Jokat, W., 2000. The sedimentary structure in the western Weddell Sea. Mar. Geol. 168, 45-60. http://dx.doi.org/10.1016/S0025-3227(00)00048-7.
Rogenhagen, J., Jokat, W., Hinz, K., Kristoffersen, Y., 2004. Improved seismic stratigraphy of the Mesozoic Weddell Sea. Mar. Geophys. Res. 25, 265-282. http://dx.doi.org/10. 1007/s11001-005-1335-y.

Shevenell, A.E., Kennett, J.P., Lea, D.W., 2004. Middle Miocene Southern Ocean cooling and Antarctic cryosphere expansion. Science 305 (5691), 1766-1770. http://dx.doi.org/ 10.1126/science. 1100061

Smith, R.T., Anderson, J.B., 2010. Ice-sheet evolution in James Ross basin, Weddell Sea margin of the Antarctic Peninsula: the seismic stratigraphic record. Geol. Soc. Am. Bull. 122 (5/6), 830-842. http://dx.doi.org/10.1130/B26486.1.

Smith, R.T., Anderson, J.B., 2011. Seismic stratigraphy of the Joinville Plateau: implications for regional climate evolution. In: Anderson, J.B., Wellner, J.S. (Eds.), Tectonic, Climatic, and Cryospheric Evolution of the Antarctic Peninsula. Geopress, American Geophysical Union, Washington DC, USA, pp. 51-61. http://dx.doi.org/10.1029/2010SP000980.

Smith, W., Wessel, P., 1990. Gridding with continuous curvature splines in tension. Geophysics 55 (3), 293-305. http://dx.doi.org/10.1190/1.1442837.

Steinberger, B., Schmeling, H., Marquart, G., 2001. Large-scale lithospheric stress field and topography induced by global mantle circulation. Earth Planet. Sci. Lett. 186, 75-91.

Uenzelmann-Neben, G., 2006. Depositional patterns at Drift 7, Antarctic Peninsula: alongslope versus down-slope sediment transport as indicators for oceanic currents and climatic conditions. Mar. Geol. 233, 49-62. http://dx.doi.org/10.1016/j.margeo.2006. 08.008 .

Wardell, N., Childs, J.R., Cooper, A.K., 2007. Advances through collaboration: sharing seismic reflection data via the Antarctic Seismic Data Library System for Cooperative Research (SDLS). In: Cooper, A.K., Raymond, C.R. (Eds.), Antarctica: A Keystone in a Changing World-Online Proceedings of the 10th ISAES: USGS Open-File Report 2007-1047, Short Research Paper 001. http://dx.doi.org/10.3133/of2007-1047.srp001 (4 pp.).

Watts, A., 2001. Isostasy and Flexure of the Lithosphere. Cambridge University Press.

Weber, M.E., Bonani, G., Fütterer, K.D., 1994. Sedimentation processes within channelridge systems, southern Weddell Sea, Antarctica. Palaeoceanography 9, 1027-1048.

Wilson, D.S., Jamieson, S.R., Barrett, J.P., Leitchenkov, G., Gohl, K., Later, D.R., 2012. Antarctic topography at the Eocene-Oligocene boundary. Palaeogeogr. Palaeoclimatol. Palaeoecol. 335-336, 24-34. http://dx.doi.org/10.1016/j.palaeo.2011.05.028.

Wilson, D.S., Pollard, D., DeConto, R., Jamieson, S.S.R., Luyendyk, B.P., 2013. Initiation of the West Antarctic ice sheet and estimates of total Antarctic ice volume in the earliest Oligocene. Geophys. Res. Lett. 40 (16), 4305-4309.

Zachos, J., Pagani, M., Sloan, L., Thomas, E., Billups, K., 2001. Trends, rhythms, and aberrations in global climate 65 Ma to present. Science 292 (5517), 686-693. http://dx.doi. org/10.1126/science.1059412.

Zachos, C.J., Dickens, R. Gerald, Zeebe, E. Richard, 2008. An early Cenozoic perspective on greenhouse warming and carbon-cycle dynamics. Nature 451, 279-283. http://dx. doi.org/10.1038/nature06588. 